\title{
Techniques for increasing the yield of stem cell-derived exosomes: what factors may be involved?
}

\author{
Zi-Yuan Feng ${ }^{\dagger}$, Qing-Yi Zhang ${ }^{\dagger}$, Jie Tan \& Hui-Qi Xie ${ }^{*}$ \\ Laboratory of Stem Cell and Tissue Engineering, Orthopedic Research Institute, Med-X Center for Materials, State Key Laboratory of \\ Biotherapy, West China Hospital, Sichuan University, Chengdu 610041, China
}

Received July 26, 2021; accepted August 11, 2021; published online October 9, 2021

\begin{abstract}
Exosomes are nano-scale extracellular vesicles secreted by cells and constitute an important part in the cell-cell communication. The main contents of the exosomes include proteins, microRNAs, and lipids. The mechanism and safety of stem cell-derived exosomes have rendered them a promising therapeutic strategy for regenerative medicine. Nevertheless, limited yield has restrained full explication of their functions and clinical applications. To address this, various attempts have been made to explore the up- and down-stream manipulations in a bid to increase the production of exosomes. This review has recapitulated factors which may influence the yield of stem cell-derived exosomes, including selection and culture of stem cells, isolation and preservation of the exosomes, and development of artificial exosomes.
\end{abstract}

exosome, stem cell, yield, therapy

Citation: Feng, Z.Y., Zhang, Q.Y., Tan, J., and Xie, H.Q. (2022). Techniques for increasing the yield of stem cell-derived exosomes: what factors may be involved? Sci China Life Sci 65, 1325-1341. https://oi.org/10.1007/s11427-021-1997-2

\section{Introduction}

Exosomes were discovered about 50 years ago, since then research to decipher their underlying mechanisms has been thriving (Anderson, 1969; Crawford, 1971). All cells can generate this type of extracellular vesicles (EVs) with an average diameter of $100 \mathrm{~nm}$ (usually in a range between 40 and $160 \mathrm{~nm}$ ) and a cup shape under an electronic microscope (Mehryab et al., 2020). The exosomes comprise a myriad of bioactive compounds, including proteins, microRNAs, lipids, and DNA segments (Ferguson and Nguyen, 2016), which play a crucial role in the interplay of diverse cells (Kowal et al., 2014; Kalluri and LeBleu, 2020). The exosomes are generated and derived from a special bilayer organelle called multivesicular body (MVB). The formation of MVB includes several phases: (1) germination, starting with

$\dagger$ Contributed equally to this work

*Corresponding author (email: xiehuiqi@scu.edu.cn) the formation of an incurvate structure at specific loci on the cell membrane; (2) formation of early-sorting endosomes (ESEs), which results in its outside-in plasma membrane orientation; (3) late-sorting endosomes (LSEs), which are matured from the ESEs when precursors of the exosomes, namely intraluminal vesicles (ILVs), are germinating, and (4) transformation to mature MVBs with ILVs lying at inside. Notably, as the formation of the exosomes is associated with specific sorting mechanisms, the compounds in such vesicles are divergent from other EVs, e.g., microvesicles, microparticles and other large vesicles, with respect to membrane proteins, lipids, and inclusions (Figure 1) (Trajkovic et al., 2008; Kowal et al., 2014; Kalluri and LeBleu, 2020). Such characteristics can also help with the discrimination of the exosomes from other vesicular structures.

Stem cell-based therapies have been tailored for the treatment of a broad range of diseases (Ratajczak et al., 2006; Bruno et al., 2019; Zakrzewski et al., 2019). Over 1,200 clinical trials involving utilization of mesenchymal stem 


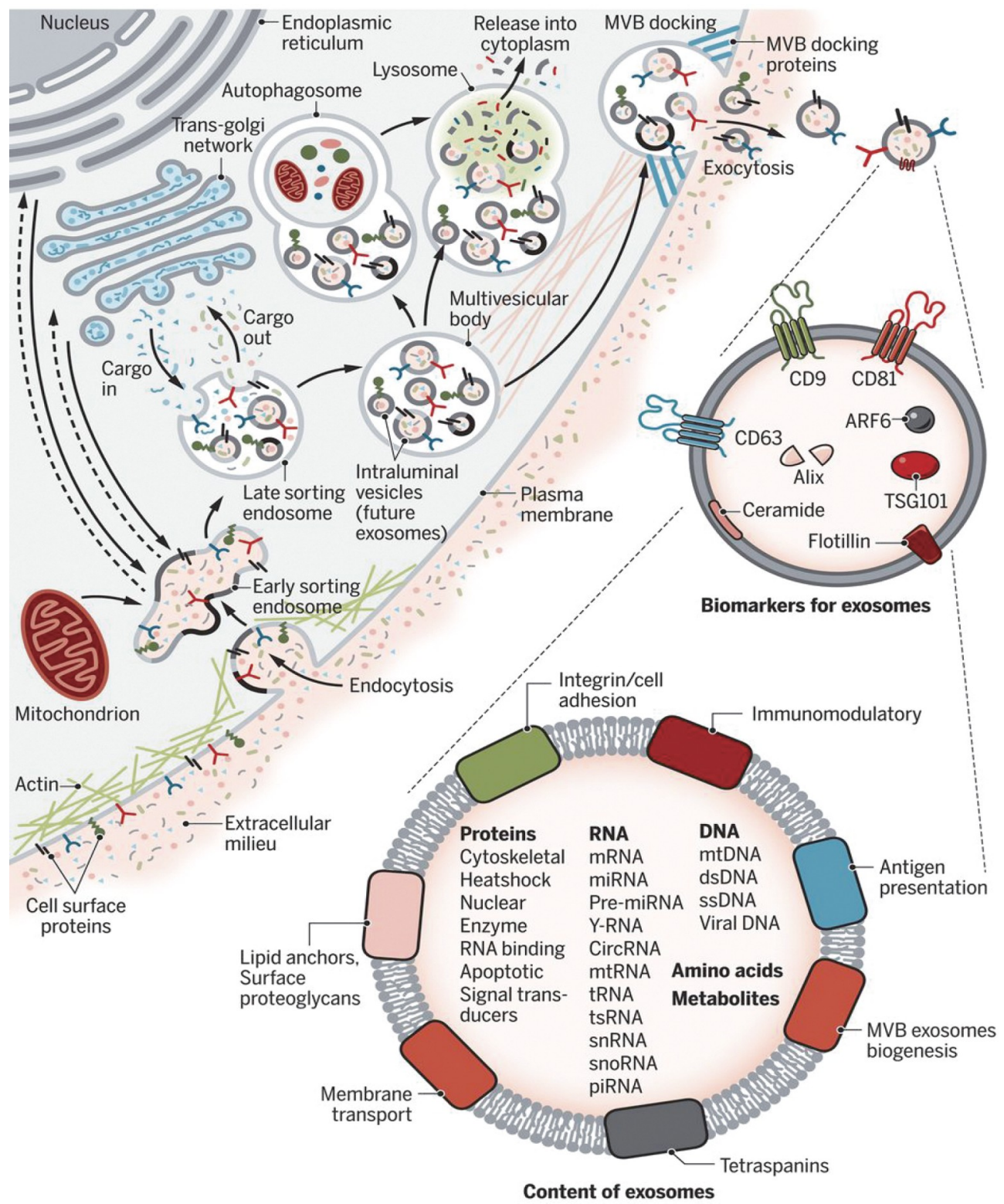

Figure 1 Biogenesis and identification of exosomes. Exosomes originate from plasma membrane, and can be followed by fusion with the endoplasmic reticulum, trans-Golgi network, and mitochondria. The process goes through several stages and involves numerous pathways including Rab GTPases and ESCRT. The exosomes contain membrane and luminal constituents, including CD9, CD63, CD81, flotillin, TSG101, ceramide, and Alix, which can be used as molecular markers (Kalluri and LeBleu, 2020).

cells (MSCs) have so far been registered in ClinicalTrials. gov (Phinney and Pittenger, 2017). Inspiringly, apparent benefit and safety have been noted in most of these trials. Stem cell-derived exosomes possess favorable pharmacokinetic property, biocompatibility, and tissue-targeting ability owing to their bilayer structures and constituents of mRNAs, microRNAs, cytokines, chemokines, and immunomodulatory compounds (Mendt et al., 2019; Harrell et al., 2019; Haraszti et al., 2019; Fernández-Francos et al., 2021). Moreover, the ability of the exosomes to suppress inflammation, regulate cell proliferation, and promote damaged tissue repair has been corroborated (Harrell et al.,
2019; Massa et al., 2020), for example, in the skin (An et al., 2021), muscle and bone (Nakamura et al., 2015; Hao et al., 2017; Mianehsaz et al., 2019), nerve (Tsintou et al., 2021), heart (Bahardoust and Baghoi-Hosseinabadi, 2021), liver (Zhao et al., 2020), kidney (Ishiy et al., 2020), lung (Xu et al., 2020), immune system (Burrello et al., 2016), cancer (Sharma, 2018), and virus infection (Jamshidi et al., 2021) (Figure 2). Introduction of the exosomes into biomaterials, such as exosome-laden hydrogel (Wang et al., 2019a; Wang et al., 2019b), exosome-coated scaffold (Zhai et al., 2020; Kyung Kim et al., 2021), and exosome-based drug delivering vectors (Barile and Vassalli, 2017; Mehryab et al., 2020), has 
also become hot topics in regenerative medicine research. Compared with stem cell-based therapies, exosome-based therapies are more promising owing to their better delineated mechanisms. Moreover, the merits of resolution of the tumorigenicity, toxicity, and immune rejection associated with cell therapy, along with the convenience to obtain the exosomes without damages to the cells, have further expanded the design and clinical application of exosome-based therapies (Kuriyan et al., 2017; Mendt et al., 2019).

Nevertheless, the feasibility of exosome-based therapies is still limited, which may be attributed to the trivial amount of the exosomes by individual cells and lack of efficient extracting strategy (Colao et al., 2018; Kalluri and LeBleu, 2020). As discovered, a dose of $800 \mu \mathrm{g} \mathrm{kg}^{-1}$ exosomes is required to render a notable clinic therapeutic effect (Lee et al., 2021). However, only about $10 \mu \mathrm{g}$ exosomes can be harvested from $1 \mathrm{~mL}$ of $2 \mathrm{D}$ static stem cell culture medium by ultracentrifugation (Patel et al., 2019; Z. Wu et al., 2021), which suggested that there is still a long way to go before real clinical application. During the last decade, research devoted to enhancing the production of exosomes has increased. Strategies to improve the yield of exosomes have included up- and downstream manipulations (Lai et al., 2010; Colao et al., 2018). Upstream manipulations included selection of stem cells with high productivity (Haraszti et al., 2018), addition of soluble factors (Wang et al., 2020), modification of culture condition (Zhu et al., 2018), and application of high-density cell culture techniques (Kim et al., 2018). Downstream manipulations comprised development of a diverse range of separation methods including gradient centrifugation, precipitation of polymers, ultrafiltration, exclusion chromatography, immunoaffinity adsorption, and microfluidics (Li et al., 2017; D. Yang et al., 2020). As another downstream manipulation, storage technologies have also been improved to facilitate the exosome-based therapy (Charoenviriyakul et al., 2018). Furthermore, artificial exosomes have also been explored for producing exosomes with low cost, high output, and homogenous quality (GarcíaManrique et al., 2018). In this review, we have systematically summarized the strategies to increase the yield of stem cellderived exosomes, with an aim to provide reference and inspiration for further research in this field.

\section{Selection of stem cells}

The generation and secretion of the exosomes are under complex regulation. Accordingly, the amount and properties of the exosomes are divergent due to their diverse origins, which may lead to discrepant therapeutic outcomes (Haraszti et al., 2016; Charoenviriyakul et al., 2017; Alvarez-Viejo, 2020). Therefore, rigorous selection of appropriate stem cells is crucial for enhancing the yield of the exosomes.
MSCs, which are well defined by the International Society for Cell and Gene Therapy (Dominici et al., 2006), are the most widely used stem cells for exosome studies. The MSCs can be further classified into several subcategories based on their source of derivation including bone marrow, adipose tissue, umbilical cord, skin, dental pulp, and menstrual blood (Lopez-Verrilli et al., 2016; Alvarez-Viejo, 2020). Among these, bone marrow mesenchymal stem cells (BMSCs), adipose mesenchymal stem cells (ADSCs), and human umbilical mesenchymal stem cells (HUMSCs) are most widely studied. As mentioned above, the constituents and therapeutic efficacy of the exosomes derived from disparate stem cells are different (Table 1) (Lopez-Verrilli et al., 2016; Börger et al., 2017; Ji et al., 2019; Alvarez-Viejo, 2020). The divergent ability of exosome secretion by different stem cells may in part account for this phenomenon. As discovered, HUMSCs can secrete exosomes by approximately 4-fold in quantity compared with BMSCs and ADSCs, while concurrently with the largest size (Haraszti et al., 2018). Meanwhile, such exosomes are also stable when cultured in serum-free medium, which is advantageous for massive production (Haraszti et al., 2019).

Other types of stem cells have also been studied, though their secreting capacity and therapeutic efficacy have not been fully explored (Yuan et al., 2018). It would be valuable to obtain comparative data on exosomes from other stem cells such as the urine-derived stem cells (Chen et al., 2018), dental pulp stem cells (Faruqu et al., 2020), and other newly discovered stem cells.

\section{Culture methods of stem cells}

The yield of exosomes can be influenced by modification of the culturing condition of stem cells, which may include adjustment of culture medium components, environment parameters or even modes of cultivation. Such factors may in turn influence the properties of exosomes and alter the productivity of the stem cells by regulating their behaviors (Table 2).

\section{Soluble factors}

A feasible way to enhance the secretion of exosomes of stem cells is by addition of certain soluble cytokines directly into the culture medium. A myriad of bioactive cytokines, including lipopolysaccharide (LPS) (Ti et al., 2015), N-methyldopamine (Wang et al., 2020), noradrenaline (Wang et al., 2020), and adiponectin (Kita and Shimomura, 2020), have been tried. In such a context, the property and therapeutic efficacy of exosomes may also be changed. Of note, some Chinese medicine, e.g., Suxiao Jiuxin pills, has been shown to contain biomolecules that can elevate the magni- 


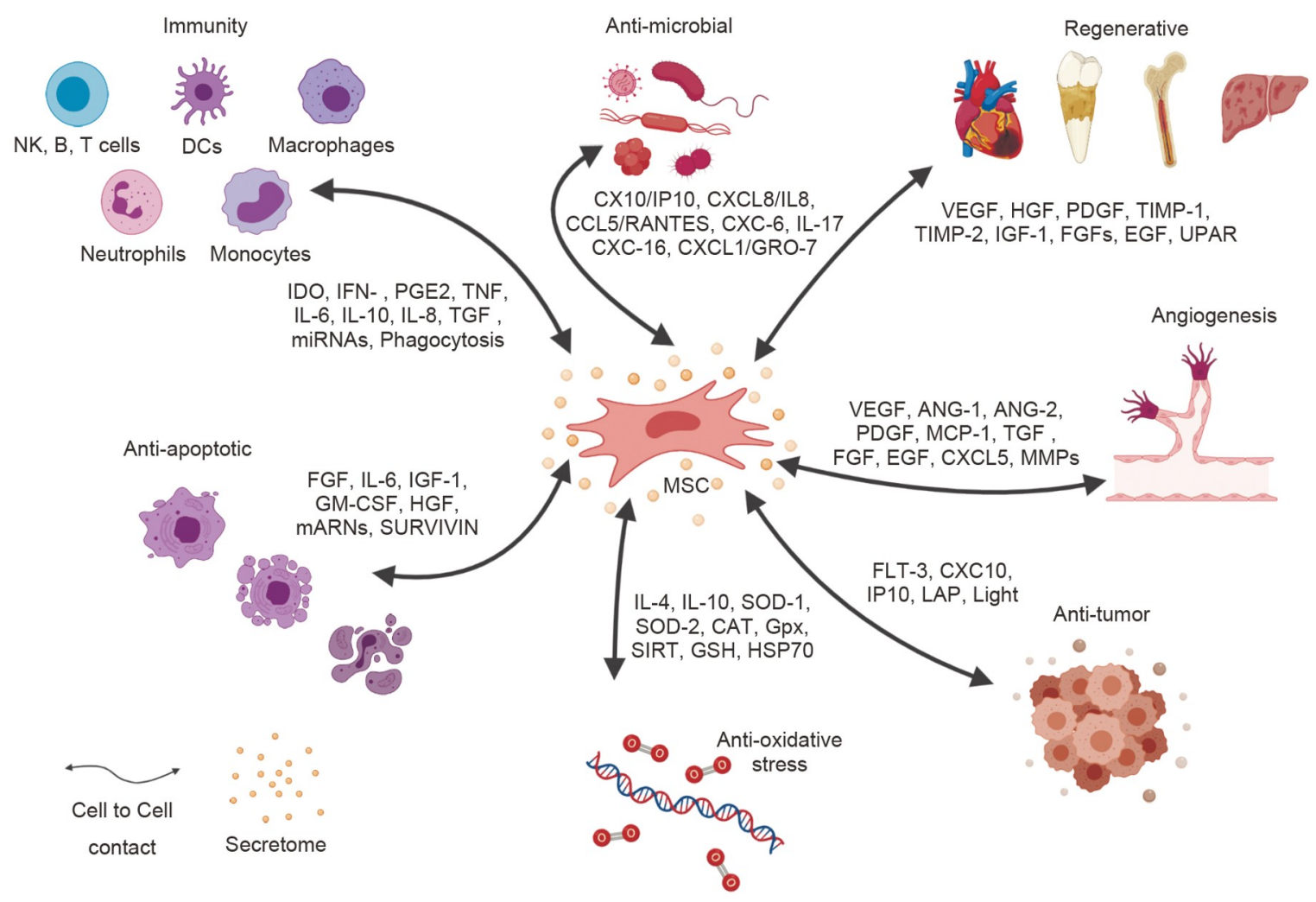

Figure 2 MSC-derived exosomes contain various bioactive compounds and have shown therapeutic benefits in many areas (Fernández-Francos et al., 2021).

Table 1 Comparison of exosomes derived from different types of stem cells

\begin{tabular}{|c|c|c|c|c|}
\hline Cellular origin & Comparison method & Exosome comparison results & Applications & Reference \\
\hline $\begin{array}{l}\text { MSCs derived from human } \\
\text { umbilical cord (HUMSCs), } \\
\text { adipose tissue (ADSCs) and } \\
\text { bone marrow (BMSCs) }\end{array}$ & $\begin{array}{l}\text { Proteomic and lipidomic changes } \\
\text { in exosome composition in the } \\
\text { absence of serum }\end{array}$ & $\begin{array}{l}\text { HUMSCs composition did } \\
\text { not show changes, while } \\
\text { BMSCs and ADSCs exosomes } \\
\text { proteins have decreased }\end{array}$ & $\begin{array}{l}\text { Optimizes conditions to improve } \\
\text { the delivery of exosomal cargo } \\
\text { and used these optimized } \\
\text { exosomes to find molecules } \\
\text { which may affect exosomal } \\
\text { activity }\end{array}$ & Haraszti et al., 2019 \\
\hline BMSCs, ADSCs, HUMSCs & $\begin{array}{c}\text { Compared the yield and diameter } \\
\text { of exosomes isolated by ultra- } \\
\text { centrifugation }\end{array}$ & $\begin{array}{l}\text { Wharton's Jelly-derived me- } \\
\text { senchymal stem cells produce the } \\
\text { most exosomes }\end{array}$ & $\begin{array}{l}\text { Produces exosomes by tangential } \\
\text { flow filtration in combination } \\
\text { with 3D MSC cultures }\end{array}$ & Haraszti et al., 2018 \\
\hline $\begin{array}{c}\text { U87 glioblastoma cells, } \\
\text { Huh7 hepatocellular } \\
\text { carcinoma cells and BMSCs }\end{array}$ & $\begin{array}{l}\text { High-resolution lipidomic and } \\
\text { proteomic analyses }\end{array}$ & $\begin{array}{c}\text { The protein patterns of exosomes } \\
\text { were more different from their } \\
\text { cells of origin compared with } \\
\text { that of MVs }\end{array}$ & $\begin{array}{l}\text { Comprehensively analyses the } \\
\text { protein and lipid composition of } \\
\text { exosomes, MVs and source cells } \\
\text { in } 3 \text { different cell types }\end{array}$ & Haraszti et al., 2016 \\
\hline $\begin{array}{c}\text { ADSCs, HUMSCs and } \\
\text { BMSCs }\end{array}$ & $\begin{array}{l}\text { Reviewed the clinical and } \\
\text { pre-clinical applications of } \\
\text { three most used exosomes }\end{array}$ & $\begin{array}{l}\text { Updated research addressing the } \\
\text { therapeutic potential of } \\
\text { exosomes }\end{array}$ & $\begin{array}{l}\text { Examines the therapeutic } \\
\text { potential of exosomes } \\
\text { obtained from sources most } \\
\text { used in cell therapy }\end{array}$ & Alvarez-Viejo, 2020 \\
\hline $\begin{array}{c}\text { Menstrual MSCs (MenSCs), } \\
\text { HUMSCs, BMSCs and } \\
\text { chorion MSCs }\end{array}$ & $\begin{array}{c}\text { Compared the effect on neuritic } \\
\text { outgrowth in primary neuronal } \\
\text { cultures }\end{array}$ & $\begin{array}{l}\text { MenSC exosomes had a similar } \\
\text { effect to BM-SC exosomes on } \\
\text { neurite outgrowth in dorsal root } \\
\text { ganglia neurons }\end{array}$ & $\begin{array}{l}\text { Raises the potential of MenSCs } \\
\text { as therapeutic conveyors in } \\
\text { neurodegenerative diseases }\end{array}$ & $\begin{array}{l}\text { Lopez-Verrilli et al., } \\
2016\end{array}$ \\
\hline $\begin{array}{l}\text { BMSCs and dental pulp } \\
\text { stem cells (DPSCs) }\end{array}$ & $\begin{array}{l}\text { Stimulated peripheral blood } \\
\text { mononuclear cells and CD4 }{ }^{+} \mathrm{T} \\
\text { cells with BMMSCs-E and } \\
\text { DPSCs-E respectively }\end{array}$ & $\begin{array}{c}\text { Capabilities of DPSCs-E } \\
\text { were greater than BMMSCs-E }\end{array}$ & $\begin{array}{c}\text { Compares the immunomodulatory } \\
\text { capacity of BMMSCs-E and } \\
\text { DPSCs-E }\end{array}$ & Ji et al., 2019 \\
\hline
\end{tabular}

tude of exosome secretion by stem cells (Ruan et al., 2018).

Unfortunately, even though the soluble factors have shown the validity in influencing the exosome secretion by stem cells, there is still a long way to go before large-scale ap- plications due to certain limitations including potential physiological status alternation and internalization of the agents into the parent cells (Silva et al., 2015; Zou et al., 2019). Hence, researchers have been reluctant to add soluble 
Table 2 Comparison of cell culture condition

\begin{tabular}{|c|c|c|c|c|}
\hline Methods & Cellular origin & Fold increase & Characteristic alternation & Reference \\
\hline \multicolumn{5}{|c|}{ Soluble factors } \\
\hline $\begin{array}{l}\text { N-methyldopamine and nore- } \\
\text { pinephrine }\end{array}$ & $\mathrm{BMSCs}$ & 3-fold & $\begin{array}{l}\text { No significant alternation in the } \\
\text { structure, composition and therapeutic } \\
\text { effect of exosomes }\end{array}$ & Wang et al., 2020 \\
\hline LPS & HUMSCs & 1.37 -fold & $\begin{array}{l}\text { Let-7b was upregulated, which } \\
\text { enhanced Immunotherapeutic effect }\end{array}$ & Ti et al., 2015 \\
\hline Adiponectin & Endothelial F2T cells & 3-fold & Adiponectin was present in exosomes & Obata et al., 2018 \\
\hline Suxiao Jiuxin pills & Cardiac MSCs & 3-fold & $\begin{array}{l}\text { Rab27a, SYTL4, Rab27b proteins and } \\
\text { the small GTPases were upregulated }\end{array}$ & Ruan et al., 2018 \\
\hline \multicolumn{5}{|c|}{ Chemical/physical stimulation } \\
\hline Serum-deprived stress & BMSCs, ADSCs, HUMSCs & $\begin{array}{l}\text { No significant improve- } \\
\text { ment }\end{array}$ & $\begin{array}{l}\text { Exosome activity was improved, while } \\
\text { MVs activity was impaired }\end{array}$ & Haraszti et al., 2019 \\
\hline Hypoxia stress & BMSCs, ADSCs, & - & $\begin{array}{l}\text { Therapeutic molecular including } \\
\text { miRNA (miR-216a-5p, miR-125b, } \\
\text { etc.) and proteins are upregulated }\end{array}$ & $\begin{array}{l}\text { Zhu et al., 2018; Liu et al., } \\
\text { 2020; Geßner et al., } 2021\end{array}$ \\
\hline Flow or stretch stimulation & $\begin{array}{l}\text { Dental MSCs, ADSCs, } \\
\text { skeletal muscle cells }\end{array}$ & $\begin{array}{l}\text { Up to } 40.7 \text {-fold, differ } \\
\text { between the cells }\end{array}$ & $\begin{array}{c}\text { Isolated EVs showed typical structure, } \\
\text { whereas } 216 \text { proteins were } \\
\text { differentially expressed }\end{array}$ & Guo et al., 2021 \\
\hline $\begin{array}{l}\text { Mechanical stimulation caused } \\
\text { by a rotary cell culture system }\end{array}$ & HUMSCs & 4-fold & $\begin{array}{l}\text { Exosome composition, especially } \\
\text { lncRNA H19, was upregulated, which } \\
\text { enhanced the therapeutic effect }\end{array}$ & L. Yan et al., 2021 \\
\hline $\begin{array}{l}\text { High frequency acoustic } \\
\text { irradiation stimulating }\end{array}$ & U87-MGcells & $8-10$-fold & $\begin{array}{l}\text { The EVs size distribution of } \\
\text { stimulated cells consisted } \\
\text { primarily of exosomes }\end{array}$ & Ambattu et al., 2020 \\
\hline \multicolumn{5}{|c|}{ 3D Culture } \\
\hline 3D spheroid culture & BMSCs & $\begin{array}{l}\text { 2-3-fold, decreased with } \\
\text { increasing 3D spheroid size }\end{array}$ & Not mentioned & Kim et al., 2018 \\
\hline $\begin{array}{l}\text { 3D-printed scaffold-perfusion } \\
\text { bioreactor system }\end{array}$ & $\begin{array}{l}\text { Human dermal microvas- } \\
\text { cular endothelial cells }\end{array}$ & $\begin{array}{l}10,000 \text {-fold by NTA, } 14- \\
\text { fold by CD } 63 \text { ExoELISA } \\
\text { and } 6.5 \text {-fold by BCA }\end{array}$ & $\begin{array}{l}\text { Total protein content per exosome } \\
\text { showed significant decrease }\end{array}$ & Patel et al., 2019 \\
\hline $\begin{array}{l}\text { Engineered 3D tissue and flow } \\
\text { bioreactor }\end{array}$ & $\begin{array}{l}\text { Dental MSCs, ADSCs, } \\
\text { skeletal muscle cells }\end{array}$ & $\begin{array}{l}\text { Up to } 40.7 \text {-fold (differ } \\
\text { between the cells) }\end{array}$ & $\begin{array}{l}\text { Isolated EVs showed typical structure, } \\
\text { whereas } 216 \text { proteins were } \\
\text { differentially expressed }\end{array}$ & Guo et al., 2021 \\
\hline Microcarrier-based 3D culture & HUMSCs & 20-fold & $\begin{array}{l}\text { Proteomics analysis showed } 357 \\
\text { high-abundance proteins detected in } \\
\text { all exosome variants and } 21-369 \\
\text { low-abundance proteins unique to an } \\
\text { exosome variant }\end{array}$ & Haraszti et al., 2018 \\
\hline \multicolumn{5}{|c|}{ Biomaterials } \\
\hline Nitric oxide-releasing polymer & $\begin{array}{l}\text { Human placenta-derived } \\
\text { MSCs }\end{array}$ & $\begin{array}{l}\text { No significant } \\
\text { improvement }\end{array}$ & $\begin{array}{l}\text { MiR-126 was upregulated, which en- } \\
\text { hanced the pro-angiogenic activity of } \\
\text { exosomes }\end{array}$ & Du et al., 2017 \\
\hline $\begin{array}{l}\text { Li-incorporated bioactive glass } \\
\text { ceramic }\end{array}$ & BMSCs & $\begin{array}{l}\text { No significant } \\
\text { improvement }\end{array}$ & $\begin{array}{c}\text { MiR-130a was upregulated, which } \\
\text { enhanced the pro-angiogenic activity } \\
\text { of exosomes }\end{array}$ & Liu et al., 2019 \\
\hline PLGA nanoparticle & BMSCs & 2-fold & $\begin{array}{l}\text { Specific antioxidants or tissue } \\
\text { regeneration factors may be increased }\end{array}$ & Park et al., 2020 \\
\hline Bioglass & BMSCs & 2-fold & $\begin{array}{l}\text { The ability of promoting ECs } \\
\text { vascularization was enhanced }\end{array}$ & Z. Wu et al., 2021 \\
\hline
\end{tabular}

factors for preserving the potential of the culture medium. In fact, the main purpose of adding soluble cytokines to the culture medium was to delineate the mechanisms by which the secretion of exosomes is regulated.

\section{Chemical/physical stimulation}

Cells may alter their characteristics to adapt to changes of their environment, and such alternations can be partially reflected by their secretions. As tissue generators, stem cells have been proven to be activated when tissue damage signals are triggered. Based on this rationale, researchers are inspired to create the damage-mimetic micro-environment chemically or physically during stem cell cultivation, with an aim to obtain exosomes with boosted production and therapeutic functions (Pusic et al., 2016; Yin et al., 2019).

Chemical stimulations such as hypoxia can influence the secretion of exosomes by the stem cells. Exosomes isolated 
from the MSCs treated with hypoxia usually exhibited an enhanced therapeutic effect (Zhu et al., 2018; Liu et al., 2020; Geßner et al., 2021). Serum deprivation was another novel means to stimulate the secretion of exosomes by the stem cells, as substances in the culture serum may also to some extent interfere with the secretion (J. Li et al., 2015; Haraszti et al., 2019). In addition, mechanical forces such as flow and stretching factors have also been shown to impact the secretion of stem cells via bioreactors, which elevated the production of EVs by up to 37-fold (Guo et al., 2021; Yan et al., 2021). Furthermore, Ambattu et al. demonstrated that stimulating cells with high-frequency ultrasound could result in an 8-10-fold increase in the yield of exosomes (Ambattu et al., 2020). However, whether such changes are attributable to the fragmented debris of cell membrane remains to be determined. Of note, the aforementioned stimulations may also impact the phenotypes of the source cells (Haraszti et al., 2019).

\section{$3 D$ culture}

Along with the development of upstream manipulation techniques, researchers have tried 3D culture for enhancing the yield of exosomes. The 3D culture can maximize the culturing area and incessantly apply a shear force (Colao et al., 2018). An early method was the hanging-drop in a 3D spheroid culture (Kim et al., 2018). However, the efficiency of this method was stagnated after a gain by only $2-3$-fold. Patel et al. increased the yield of exosomes by nearly 100 fold by culturing the cells on a $3 \mathrm{D}$ printed hollow fibrillar scaffold with a complementary perfusion system (Patel et al., 2019). However, subsequent experiments have found that the morphology and component of exosomes were significantly altered. The membrane proteins were critically decreased through such a process. Worse still, the fabrication procedure of this 3D-printing scaffold was too complex to be widely adapted.

Microcarrier-based suspension culture is so far the most suitable platform for 3D stem cell cultivation and has been extensively used for commercialized production (Tavassoli et al., 2018; Koh et al., 2020). The method was firstly applied in 2015 for the extraction of the exosomes (Jarmalavičiùte et al., 2015). Researchers noted that, compared with the other two types of MSCs (BMSCs and ADSCs), HUMSCs derived from Wharton's jelly had the highest yield of exosomes, and the output could be further increased by approximately 20 fold when a microcarrier suspension culture system was applied, or even 140-fold when a tangential flow filtration system was introduced (Haraszti et al., 2018). This work was subsequently adapted by Xu et al. for the development of an exosome-based therapy (Ling et al., 2020). Furthermore, a bioreactor system invented by Tsinghua University has proven to be convenient for large-scale production of stem cell-derived exosomes (Yan et al., 2020). Nevertheless, the culturing parameter and shear stress during suspension cultivation should be carefully evaluated in order to limit cell death and phenotype transformation (Becquart et al., 2016).

\section{Biomaterials}

The materials of culture substrate may provide another avenue for increasing the yield of stem cell-derived exosomes. Typical examples include NO-releasing polymer (Du et al., 2017), lithium-incorporated bioactive glass ceramic (Liu et al., 2019), ferroferric oxide coated PLGA nanoparticles (Park et al., 2020) and bioglass (Z. Wu et al., 2021). In addition to the productivity, biomaterials could also improve the therapeutical efficacy of exosomes by forming a specific micro-environment to interact with the cells, which may to some extent determine the fate of stem cells (Novoseletskaya et al., 2019). Although many biomaterials have been demonstrated to influence the paracrine of stem cells (Peng et al., 2017), definite validations regarding the exosomes are scarce. Nevertheless, biomaterials and cultivation technologies could be combined, for instance, by extracellular matrix (ECM)-derived microcarriers, to further enhance the secretion of exosomes by stem cells (Turner and Flynn, 2012; Kornmuller et al., 2017).

\section{Isolation of exosomes}

In addition to the aforementioned upstream manipulations, isolation techniques are also critical to increase the yield of exosomes. Currently available techniques for the extraction of exosomes are mainly based on their chemical, physical, and immunological properties, and are adapted from the methods used for the extraction of virus and microvesicles, such as ultracentrifugation, polymer precipitation, ultrafiltration, exclusion chromatography, immunoaffinity chromatography, and microfluidics. To date, technology and facility designed exclusively for the extraction of exosomes are scarce (Li et al., 2017; Lane et al., 2017; D. Yang et al., 2020). Similar to upstream manipulations, the selection of extracting methods may impact not only the yield of exosomes, but also their characteristics such as size, structure, and biofunction (Rekker et al., 2014) (Table 3). Hence, isolation methods should be carefully selected based on the aim of research as well as characteristics of the method and sample. Notably, with proper combination, up- and downstream manipulations could be integrated in a multiplicative manner to increase the total yield of exosomes substantially.

\section{Centrifugation and sedimentation}

Differential ultracentrifugation, or ultracentrifugation, has 
Table 3 Exosome isolation techniques

\begin{tabular}{|c|c|c|c|c|c|c|}
\hline Isolation technique & Principle & Sample volume & Process time & Purity & Recovery & Reference \\
\hline $\begin{array}{c}\text { Differential } \\
\text { ultracentrifugation }\end{array}$ & Sedimentation rate & 100 s of $\mathrm{mL}$ & $3-6 \mathrm{~h}$ & Low & $5 \%-20 \%$ & $\begin{array}{c}\text { Tauro et al., 2012; Nordin } \\
\text { et al., 2015 }\end{array}$ \\
\hline Gradient ultracentrifugation & Density, size and shape & $\sim 1 \mathrm{~mL}$ & $20-24 \mathrm{~h}$ & High & $10 \%-40 \%$ & Tauro et al., 2012 \\
\hline Polymer precipitation & Sedimentation rate & $>100 \mu \mathrm{L}$ & $2-18 \mathrm{~h}$ & Low & $5 \%-30 \%$ & $\begin{array}{l}\text { Y. Tang et al., 2017; } \\
\text { Börger et al., } 2020\end{array}$ \\
\hline Ultrafiltration & Size & $\sim 10 \mathrm{~mL}$ & $1-3 \mathrm{~h}$ & Moderate & $\sim 30 \%$ & Nordin et al., 2015 \\
\hline Tangential flow filtration & Size & $100 \mathrm{~s}$ of $\mathrm{mL}$ & $1-2 \mathrm{~h}$ & Moderate & $\sim 80 \%$ & Busatto et al., 2018 \\
\hline $\begin{array}{l}\text { Size-exclusion } \\
\text { chromatography }\end{array}$ & Size & $\sim 1 \mathrm{~mL}$ & $1-2 \mathrm{~h}$ & Moderate & $40 \%-80 \%$ & $\begin{array}{l}\text { Gámez-Valero et al., } \\
\text { 2016; Moleirinho et al., } \\
2019\end{array}$ \\
\hline Immunoaffinity capture & Surface marker expression & $\sim 100 \mu \mathrm{L}$ & $18-20 \mathrm{~h}$ & Very high & $>90 \%$ & Foroni et al., 2020 \\
\hline $\begin{array}{l}\text { Microfluidics-based } \\
\text { techniques }\end{array}$ & $\begin{array}{c}\text { Surface marker expression, } \\
\text { size, density, etc. }\end{array}$ & $\sim 100 \mu \mathrm{L}$ & $1-3 \mathrm{~h}$ & High & $40 \%-90 \%$ & $\begin{array}{c}\text { Liu et al., 2017; Han et } \\
\text { al., } 2021\end{array}$ \\
\hline
\end{tabular}

remained the standard method for extracting exosomes. The rationale behind this technique is that cell fragments, apoptotic bodies, and other large-size components in the culture medium can be separated according to their respective volume, density, and morphology (Witwer et al., 2013; Zarovni et al., 2015). Despite that ultracentrifugation has a high productivity and is easy to use, its clinical translation is limited due to low specificity, time-consuming, requirement of expensive device, difficulty in extracting exosomes from small-sized sample, and the causally occurred fusion of the extracted exosomes.

Density-gradient centrifugation can overcome the drawback of lacking specificity in ultracentrifugation by a special density-gradient medium method, which can be further classified into two categories, i.e., the isopycnic and movingzone density-gradient centrifugation (D. Yang et al., 2020; Li et al., 2017). For isopycnic density-gradient centrifugation, the medium (usually comprised of sucrose and iodixanol) was set in a tapered density gradient from the bottom to the top. By this way, the dissolved substances with similar density will stay in a same layer, thus separating the exosomes from other compounds with large density discrepancy (Greening et al., 2015; D. Yang et al., 2020). Nevertheless, it is still difficult to separate the EVs with similar densities, resulting in impurity of exosomes.

In order to isolate the exosomes from other compounds with similar densities such as MVs, a moving-zone densitygradient centrifugation technique was developed, where a centrifugal medium with a density lower than other solvents was used. All dissolved substances in the system are incessantly moving during centrifugation (Li et al., 2017; D. Yang et al., 2020). Therefore, by carefully calculating the parameters of the exosomes and other compounds (such as MVs) and setting the centrifugation time, the exosomes could be isolated according to their disparate size, mass as well as density (D. Yang et al., 2020). Even though such procedures are sophisticated, tedious, and with limited handling capacity compared with the ultracentrifugation method, it has the advantages of high specificity, broad application, and higher output, which have rendered it a suitable alternative for extracting special exosomes from media with limited sample availability, e.g., plasma and other biofluids (Greening et al., 2015).

Of note, polymer precipitation has been reported to efficiently increase the sedimentation rate of exosomes, which could decrease the centrifugal force required for extracting exosomes. The polymers can absorb the water on the surface of exosomes, making them easier to precipitate even at a lower centrifugation speed, thus producing exosomes with simpler equipment in less time. Furthermore, low cost and convenience to manipulate are also merits of polymer precipitation (Zeringer et al., 2015). Unfortunately, soluble proteins may also be precipitated during this process, thus affecting the purity of extracted exosomes (Lane et al., 2017). To this end, researchers are endeavored to improve the sample capacity of polymer precipitation, for instance, by introduction of PEG (Börger et al., 2020) and protamine (Deregibus et al., 2016). Currently, the majority of commercially available extracting kits, such as ExoQuick and Total Exosomes Isolation, are adapted from such methods (Ryu et al., 2020).

\section{Size-based technique}

For the tiny size of the exosomes, it is feasible to separate them from proteins and other large EVs. Ultrafiltration is a method for extracting the exosomes by their difference in size (Zeringer et al., 2015; Cardoso et al., 2021). As reported, ultrafiltration technique not only can filter out small-size compounds to obtain relatively pure exosomes, but also has the advantages of rapidity, stability, automation, and higher recovery, which may further expand its application in the 
future (Heinemann et al., 2014). However, EVs with a larger size may rupture owing to the powerful stress during filtration, which may release other inclusions to contaminate the exosomes. Meanwhile, blockade and rupture of the filter membrane are often inevitable (Batrakova and Kim, 2015).

As a result, tangential flow filtration (TFF) strategy, a method originally used for extracting viruses and proteins, was adapted to prevent the filtrated particles from damage, possibly by allowing the dissolved substances to tangentially filtrate through the membrane. During the TFF, samples can be re-circulated to repeat the process several times to improve the recovery of exosomes (Haraszti et al., 2018; Busatto et al., 2018; Han et al., 2021). Given the advantage of high sample capacity and automation, and the ability to isolate exosomes with high purity, it is possible to produce stem cell-derived exosomes on an industrial scale by using TFF.

Exclusion chromatography technology has also been tested for it can gently isolate the exosomes without ultracentrifugation (Lai et al., 2010; Cardoso et al., 2021). Despite the low recovery, the purity of exosomes obtained in this way is comparable to that by density gradient ultracentrifugation, while structure disruption caused by the centrifugal force may be avoided (Lobb et al., 2015). Nevertheless, it is difficult for such method to separate the exosomes from other vesicles or particles with similar diameters such as MVs and protein polymers.

\section{Immune-based technique}

Accurate identification of the copious surface markers such as CD9, CD63, CD81, and phosphoryl serine (Kosaka et al., 2013; Montecalvo et al., 2013) is critical for the development of specific antibodies and receptors to bind with such protein markers to capture the exosomes. As reported, exosomes extracted from $450 \mu \mathrm{L}$ medium by immunoaffinity was equal to the amount extracted from $2.5 \mathrm{~mL}$ medium by ultracentrifugation (Zarovni et al., 2015; Y. Tang et al., 2017). Apart from immunoaffinity column chromatography, magnetic pellets with immobilized antibodies have also been widely utilized for the separation and validation of the exosomes (Clayton et al., 2001; McBride et al., 2017). Immunoaffinity methods may suit exosome research perfectly by generating a high purity product with a good recovery rate. On the other hand, drawbacks such as high cost and sophisticated manipulation have limited its application on a larger scale (Foroni et al., 2020). To further improve the efficiency of extracting exosomes by immunoaffinity extraction, a method based on immunoassay upon mass spectrometry has been developed (Ueda et al., 2014).

\section{Microfluidics}

Among the newly developed strategies for extracting and analyzing the exosomes, microfluidics has been the mostly studied and adapted. By this means, the extracting device can precisely isolate the exosomes based on their physical and chemical properties. Other isolation strategies, such as tangential flow filtration (Han et al., 2021), can be integrated with the microfluidic chip and greatly improve the efficiency and specificity of exosome extraction, in particular for smallsized samples (Liu et al., 2017; Contreras-Naranjo et al., 2017).

The strategies of microfluidics used for the extraction of exosomes have included not only the surface antigen, density and size recognition, but also elastic lift force (Liu et al., 2017), ultrasonic waves (Lee et al., 2015), and electrophoretic manipulations (Ayala-Mar et al., 2019), whilst the dissociation strategies can be classified into contact type and non-contact type (D. Yang et al., 2020). Based on such technology, multilayer micro-nano fluid technology was developed to further improve the efficiency of exosome extraction (Sundaram et al., 2020). Due to its low sample handling capacity, microfluidic technologies have often been applied to analyze exosomes from smallsized samples. Nevertheless, integration of exosome manipulations with highly automated mode is still worthy to explore.

\section{Others}

For the resemblance between the viruses and macromolecules in exosomes, technologies used for the extraction of viruses have been used for the extraction of exosomes. These included flow field-flow fractionation (Kang et al., 2008; Zhang and Lyden, 2019), static water filtration dialysis (Musante et al., 2014), etc. As mentioned above, a PEG precipitation technique, originally used for virus extraction, has demonstrated a high efficiency to extract exosomes from several liters of culture medium at a time (Börger et al., 2020). Furthermore, considering the similarity between exosomes and other nanoparticles, it is feasible to extract exosomes in any laboratory equipped with facilities for the extraction of proteins and viruses.

To overcome the shortcoming of individual method, combined techniques have been tested. For instance, the isopycnic gradient ultracentrifugation and ultrafiltration can be combined, for which the isopycnic gradient ultracentrifugation is efficient to separate particles with different densities, while the ultrafiltration can subsequently purify the exosomes according to their size. Zhang et al. (2021) have developed a method called immunomagnetic sequential ultrafiltration, which consists of a tangential flow filtration step and a magnetic-bead antibody-based EV capture step. The combination of ultrafiltration and size-exclusion chromatograph is also a novel strategy worthy of consideration (Nordin et al., 2015; Cardoso et al., 2021). 


\section{Storage of exosomes}

Storage of exosomes also bears a great deal of importance. Without eligible storage technology, long-term storage cannot be achieved. In this circumstance, exosomes have to be produced whenever a demand emerges, which can severely increase the burden to the packaging, transportation, and preparation. Therefore, it is necessary to develop a method to store the exosomes in a relatively gentle condition with easy access.

Ambient temperature and time are recognized as the most crucial elements affecting the viability and quantity of the exosomes stored, as bioactive proteins in the exosomes will gradually degrade with the increase of temperature and storage time (Oosthuyzen et al., 2013; Welch et al., 2017; Jeyaram and Jay, 2017; Qin et al., 2020). By contrast, membrane proteins, DNA and RNA in the exosomes seem to be insignificantly affected by the storage temperature (Zonneveld et al., 2014; Ge et al., 2014; Sarker et al., 2014; Jin et al., 2016). As discovered, $-80^{\circ} \mathrm{C}$ is the optimal temperature for the storage of exosomes, at which the loss of bioactive proteins and exosomes can be efficiently suppressed (Jeyaram and Jay, 2017). However, the properties of exosomes will still degrade to some extent during the storage (Maroto et al., 2017). Wu et al. have systemically explored change of the property of the exosomes stored at various temperatures, and found $-80^{\circ} \mathrm{C}$ to be the optimum temperature for the long-term storage (J. Wu et al., 2021).

To enhance the stability of exosomes, certain additives were introduced into the stock solution. For instance, addition of certain protease inhibitors into the storage solution has proven to be beneficial to protect the compounds in exosomes from degradation (Oosthuyzen et al., 2013). Furthermore, combination of thawing (Zhou et al., 2006) with certain preservative agents such as DMSO, sucrose, and mycose (Tegegn et al., 2016) are also helpful for improving the recycle rate of the exosomes. Researchers even proposed an assessment system to evaluate the degradation of the EVs stored under various conditions, which has provided a precious reference for research in this field (Richter et al., 2019).

Although exosomes have shown a fare stability when stored at $-80^{\circ} \mathrm{C}$, this temperature may be unrealizable in most factories during the fabrication and transportation of exosomes. A more convenient and efficient storage condition is therefore required. Lyophilization, which is commonly used for the preservation of bioactive compounds, has been adopted for the storage of exosomes (El-Nesr et al., 2010). Although this method has carried a risk of disrupting the membrane of exosomes, it still represents an optimum solution for the storage of the exosomes when protective agents are introduced (Bahr et al., 2020). Moreover, as discovered, the exosomes could be stored for more than a week at room temperature with minimal loss in quantity and bioactive compounds with the introduction of cryoprotectant mycose (Charoenviriyakul et al., 2018). The efficacy of such technique was found to be similar to that with storage at $-80^{\circ} \mathrm{C}$. Furthermore, spray drying, a method often used for preparation and storage of unstable drugs, may also be considered for the storage of exosomes (Bahr et al., 2020).

\section{Artificial exosomes}

As aforementioned, exosomes are bioactive compounds with complex components and can act as nanoscale tools for cell communication. Such characteristics have conferred them with excellent targeting ability and biocompatibility (van der Meel et al., 2014; Yáñez-Mó et al., 2015; Surman et al., 2019). As discovered, a diversity of membrane proteins, e.g., CD47, a marker highly expressed by cancer cells for evading the immunophagocytosis, is the main contributor to the therapeutic effect of exosomes (Kamerkar et al., 2017). Incorporation of gold particles on exosome membranes can confer them with an ability to escape immunophagocytosis (Van Deun et al., 2020). Accordingly, by producing stem cell-derived exosomes artificially, the steps and/or the time taken by the stem cells to secrete exosomes may be saved, thereby increasing the yield of exosomes. To produce more homogenous exosomes on a large scale, artificial exosomes have been considered as biomolecules as they are relatively clear and can be controlled to some extent (Figure 3).

\section{Genetic engineering}

Gene-editing technique represents as a novel and powerful means for modifying the exosomes derived from stem cells (Li et al., 2018). Researchers have improved the therapeutic outcome of certain diseases by over-expressing bioactive compounds such as miR-181-5p (Qu et al., 2017), miR-214 (Shi et al., 2021), and miR-155-5p (Damasceno et al., 2020) in the MSCs. Sterzenbach et al. have fabricated a drug vector to penetrate the blood-brain barrier by modifying the ESCRT-associated genes (Sterzenbach et al., 2017). To make the stem cell-based exosomes as an optimal drug carrier, importation of some unmodified bioactive compounds (such as miRNAs) directly into the isolated exosomes by $\mathrm{CaCl}_{2}$ or electroporation has also been explored (Zhang et al., 2017; Liu and $\mathrm{Su}, 2019$ ).

Although gene-modified strategy has substantially advanced our understanding of the secretion and synthesis of exosomes, the exploration to increase the yield of exosome by such techniques is still in its infancy (Kowal et al., 2014; Kalluri and LeBleu, 2020). Various pathways, e.g., the ESCRT protein and Rab GTPase, have been found to play a critical role in the synthesis and secretion of exosomes (Katzmann et al., 2001; Ostrowski et al., 2010; Li et al., 


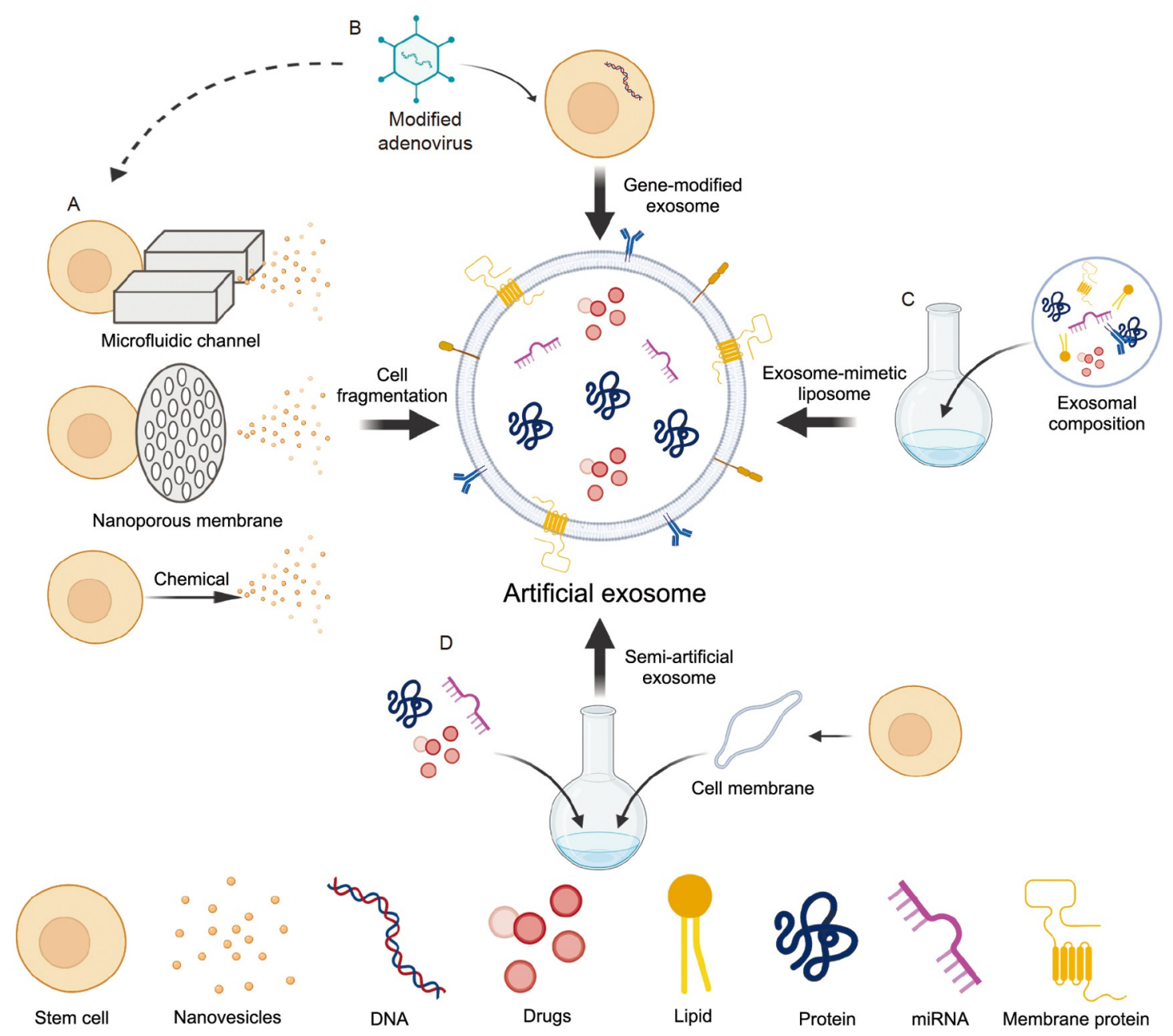

Figure 3 Artificial exosomes can be fabricated by various strategies. A, Fragmentation of the stem cells by mechanical force or chemical methods for producing artificial exosomes. B, Gene-editing techniques for producing artificial exosomes. C, Materials with appropriate physical and chemical properties are selected to produce artificial exosomes. D, Cell membrane and package of drugs and bioactive proteins are incorporated for producing artificial exosomes.

2018). Recently, researchers have also made an endeavor to upregulate the expression of genes associated with exosome secretion, including the ESCRT-III-Associated Protein Alix (Ji et al., 2021), HIF-1, and mTORC1 (Zou et al., 2019). Meanwhile, study of the culture condition has also identified other pathways such as Rab GTPase (Ruan et al., 2018; Z. Wu et al., 2021) and YAP (Guo et al., 2021) associated with exosome releasing. Such findings could be leveraged in combination to produce stem cells with an exosome-productive genotype, in this way the application of exosomes may be extensively expanded. However, certain compounds, such as ceramide (Dreux et al., 2012) and cholesterol (Strauss et al., 2010), not only are correlated with exosome synthesis, but also have influences on other intracellular metabolic activities. For this reason, the consequences elicited by gene-editing are still hard to predict. More importantly, exosomes and virus share certain similarities in multiple layers, thus the risk of contaminating the exosomes with undesirable virus genes is inevitable (Colao et al.,
2018). Such shortcomings should be overcome prior to application of such techniques for massive exosome yielding.

\section{Cell fragmentation}

Fragmentation of the cells into nanovesicles with a size equal to that of exosomes has also turned out to be a promising strategy (García-Manrique et al., 2018). Copious membrane proteins and special lipids are typical features of exosomes (Haraszti et al., 2019). All membrane proteins and lipids of the source cells could be utilized for the manufacture of exosomes (Goh et al., 2017). Accordingly, microfluidics can squeeze the cells into a hydrophilic channel to fragment them into exosome-analogous nanovesicles, by which abundant miRNA and surface proteins may be produced (Jo et al., 2014). Furthermore, cutting the cells with silicon nitride blades during their passage through the microfluidic channels can generate a more homogenous batch of exosomes (Yoon et al., 2015). Such cells can be further fragmented to 
nanovesicles by replacing the blade with centrifugation or electricity to force them to cross a nano-membrane (Jo et al., 2014; Lee et al., 2020). Other chemical methods such as radioimmunoprecipitation analysis have also been used to produce nanovesicles with a size similar to that of exosomes (Martinelli et al., 2020). Notably, combination of the aforementioned techniques with gene expression modifications, such as miRNA overexpression, has also been tested ( $\mathrm{Z}$. Yang et al., 2020).

\section{Exosome mimetic liposome}

The methods for fabricating artificial exosomes are diverse. Liposome, an artificially-made vesicle composed of lipid and cholesterol, possesses sound biocompatibility and drug loading capacity. However, clinical applications of liposomes are scarce due to their undesirable immunogenicity and unsatisfactory stability, biocompatibility, targeting ability, and absorbability (Antimisiaris et al., 2018; Guimarães et al., 2021). Such drawbacks can be largely overcome by fabricating an exosome-liposome complex, by which the advantages of two can complement each other (Haraszti et al., 2019; Sakai-Kato et al., 2020). In theory, artificial exosomes with their laden nucleic acid antigen can be employed to target dendritic cells by the self-assembly of microemulsion micelle. In such artificial exosomes, lecithin, choles- terol, dioleoacylphosphatidy-lethanolamine (DOPE), DCChol, and NBD-PE are leveraged to fabricate the lipid membranes, while the monoclonal antibody DEC205 and fetal bovine serum (BSA) are used to fabricate the surface proteins (K. Li et al., 2015). Furthermore, a pulsed jet method has also been developed to produce nanovesicles with lipid compositions analogous to those of exosomes (Kamiya et al., 2021). Although chemical synthesis of exosomes is still in its infancy, their prospect for the management of intractable diseases such as autoimmunity and tumors has already attracted much attention (Schiffelers et al., 2012; Vázquez-Ríos et al., 2019). Meanwhile, particular moieties of the naturally derived exosomes have also been used as raw material to synthesize artificial exosomes and to study their underlying mechanisms (Haraszti et al., 2019).

\section{Semi-artificial exosome}

Semi-artificial exosomes may also be used for improving the function and yield of stem cell-derived exosomes. By fusing extracellular vesicles with drug-laden liposomes (by co-incubating with PEG or without), researchers have successfully fabricated a hybrid exosome with outstanding cargo capacity, absorbability, and targeting ability, which may ultimately yield better therapeutic outcomes (Piffoux et al., 2018; Lin et al., 2018). The biocompatibility and targeting

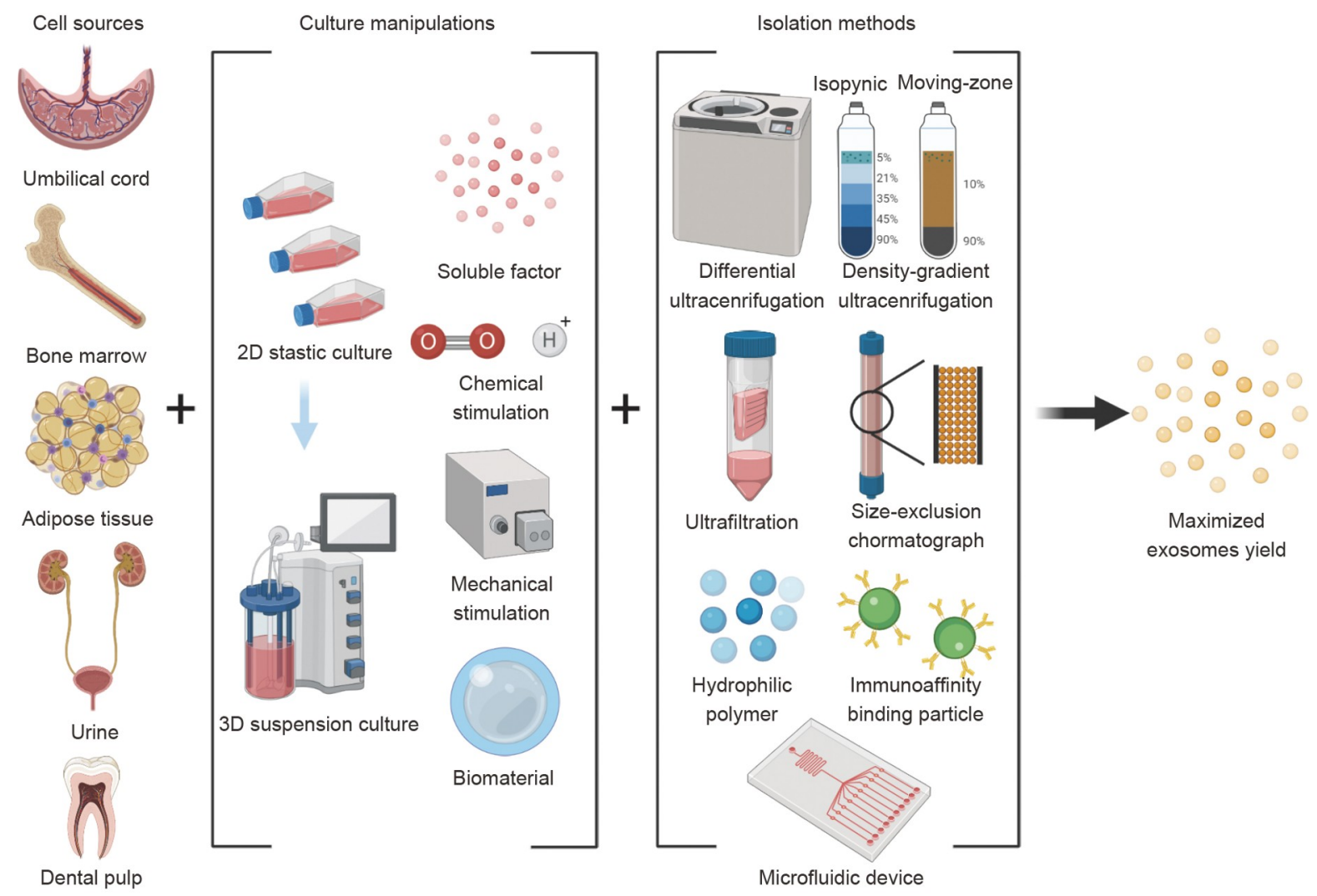

Figure 4 Methods that can maximize the yield of exosomes, in which the cell sources, culture manipulations, and isolation techniques can be adopted to increase the yield of exosomes. 
ability of such nanovesicles may also be substantially improved by, for instance, encapsulating drug-laden liposomes with MSCs-derived plasma membranes (Toledano Furman et al., 2013; Yao et al., 2020) or filling the PLGA microparticles with bioactive compounds (Luo et al., 2017). Researchers have developed a system which has incorporated the secretome of myocardial cells into the PLGA particles and covered such particles with cardinal cell membranes. Subsequent experiments demonstrated that such artificial exosomes are highly efficient in treating cardiac infarction (J. Tang et al., 2017). Encapsulation of monoclonal antibody coupled with nanovesicles into the stem cell membranes has also proven to be feasible to render the exosome-mimetic particles with sound biocompatibility and targeting ability (Li et al., 2018). The technique can be further combined with genetic editing to improve the property of semi-artificial exosomes. Compared with fully artificial exosomes, semiartificial exosomes have the advantage of requiring simpler facility. By combining their respective advantages, the application of such techniques may be further expanded.

\section{Conclusion and outlook}

Research on stem cell exosomes has attracted much attention as such nanovesicles hold great promise for biotherapy, though the majority of them are still in the preclinical phase due to the low yield of exosomes. As recapitulated in this review, factors such as cell source, culture condition and method, and isolation and storage can all have a great influence on the yield as well as the property of exosomes. A standard guideline for the manufacture is therefore needed to reduce the heterogeneity of exosomes whilst increase their yield.

Strategies to improve the yield of exosomes may be identified through combination of currently available methods. For instance, 3D microcarrier-based suspension culture may increase the output of exosomes when certain soluble factors and/or bioactive materials which are used as a biological microcarrier are applied (Haraszti et al., 2018; Patel et al., 2019) (Figure 4). Furthermore, full or semi-artificial exosomes may also be tested for massive production due to their relatively controllable composition and clear therapeutic pathway (García-Manrique et al., 2018; Surman et al., 2019). In the future, with various portfolios of aforementioned strategies combined, an optimal way to produce the desirable exosomes may be identified.

Compliance and ethics The author(s) declare that they have no conflict of interest, and all authors have agreed with the publication of this article.

Acknowledgements This work has been sponsored by the National Natural Science Foundation of China (31771065), Sichuan Science and Tech- nology Program (2019JDRC0020), and the "1.3.5 Program for Disciplines of Excellence," West China Hospital, Sichuan University (ZYJC18002).

\section{References}

Alvarez-Viejo, M. (2020). Mesenchymal stem cells from different sources and their derived exosomes: A pre-clinical perspective. World J Stem Cells 12, 100-109.

Ambattu, L.A., Ramesan, S., Dekiwadia, C., Hanssen, E., Li, H., and Yeo, L.Y. (2020). High frequency acoustic cell stimulation promotes exosome generation regulated by a calcium-dependent mechanism. Commun Biol 3, 553.

An, Y., Lin, S., Tan, X., Zhu, S., Nie, F., Zhen, Y., Gu, L., Zhang, C., Wang, B., Wei, W., et al. (2021). Exosomes from adipose-derived stem cells and application to skin wound healing. Cell Prolif 54, e12993.

Anderson, H.C. (1969). Vesicles associated with calcification in the matrix of epiphyseal cartilage. J Cell Biol 41, 59-72.

Antimisiaris, S.G., Mourtas, S., and Marazioti, A. (2018). Exosomes and exosome-inspired vesicles for targeted drug delivery. Pharmaceutics 10 , 218.

Ayala-Mar, S., Gallo-Villanueva, R.C., and González-Valdez, J. (2019). Dielectrophoretic manipulation of exosomes in a multi-section microfluidic device. Mater Today-Proc 13, 332-340.

Bahardoust, M., and Baghoi-Hosseinabadi, Z. (2021). Role of adiposederived mesenchymal stem cells in the regeneration of cardiac tissue and improvement of cardiac function: a narrative review. Biointerface Res Appl Chem 11, 8446-8456.

Bahr, M.M., Amer, M.S., Abo-El-Sooud, K., Abdallah, A.N., and ElTookhy, O.S. (2020). Preservation techniques of stem cells extracellular vesicles: a gate for manufacturing of clinical grade therapeutic extracellular vesicles and long-term clinical trials. Int J Vet Sci Med $8,1-8$.

Barile, L., and Vassalli, G. (2017). Exosomes: Therapy delivery tools and biomarkers of diseases. Pharmacol Ther 174, 63-78.

Batrakova, E.V., and Kim, M.S. (2015). Using exosomes, naturallyequipped nanocarriers, for drug delivery. J Control Release 219, 396405.

Becquart, P., Cruel, M., Hoc, T., Sudre, L., Pernelle, K., Bizios, R., Logeart-Avramoglou, D., Petite, H., and Bensidhoum, M. (2016). Human mesenchymal stem cell responses to hydrostatic pressure and shear stress. Eur Cell Mater 31, 160-173.

Börger, V., Bremer, M., Ferrer-Tur, R., Gockeln, L., Stambouli, O., Becic, A., and Giebel, B. (2017). Mesenchymal stem/stromal cell-derived extracellular vesicles and their potential as novel immunomodulatory therapeutic agents. Int J Mol Sci 18, 1450.

Börger, V., Staubach, S., Dittrich, R., Stambouli, O., and Giebel, B. (2020). Scaled isolation of mesenchymal stem/stromal cell-derived extracellular vesicles. Curr Prot Stem Cell Biol 55, e128.

Bruno, S., Chiabotto, G., Favaro, E., Deregibus, M.C., and Camussi, G. (2019). Role of extracellular vesicles in stem cell biology. Am J Physiol-Cell Physiol 317, C303-C313.

Burrello, J., Monticone, S., Gai, C., Gomez, Y., Kholia, S., and Camussi, G. (2016). Stem cell-derived extracellular vesicles and immunemodulation. Front Cell Dev Biol 4, 83.

Busatto, S., Vilanilam, G., Ticer, T., Lin, W.L., Dickson, D.W., Shapiro, S., Bergese, P., and Wolfram, J. (2018). Tangential flow filtration for highly efficient concentration of extracellular vesicles from large volumes of fluid. Cells 7, 273.

Cardoso, R.M.S., Rodrigues, S.C., Gomes, C.F., Duarte, F.V., Romao, M., Leal, E.C., Freire, P.C., Neves, R., and Simões-Correia, J. (2021). Development of an optimized and scalable method for isolation of umbilical cord blood-derived small extracellular vesicles for future clinical use. Stem Cells Transl Med 10, 910-921.

Charoenviriyakul, C., Takahashi, Y., Morishita, M., Matsumoto, A., Nishikawa, M., and Takakura, Y. (2017). Cell type-specific and common characteristics of exosomes derived from mouse cell lines: Yield, physicochemical properties, and pharmacokinetics. Eur J Pharm 
Sci 96, 316-322.

Charoenviriyakul, C., Takahashi, Y., Nishikawa, M., and Takakura, Y. (2018). Preservation of exosomes at room temperature using lyophilization. Int J Pharm 553, 1-7.

Chen, C.Y., Rao, S.S., Ren, L., Hu, X.K., Tan, Y.J., Hu, Y., Luo, J., Liu, Y. W., Yin, H., Huang, J., et al. (2018). Exosomal DMBT1 from human urine-derived stem cells facilitates diabetic wound repair by promoting angiogenesis. Theranostics 8, 1607-1623.

Clayton, A., Court, J., Navabi, H., Adams, M., Mason, M.D., Hobot, J.A., Newman, G.R., and Jasani, B. (2001). Analysis of antigen presenting cell derived exosomes, based on immuno-magnetic isolation and flow cytometry. J Immunol Methods 247, 163-174.

Colao, I.L., Corteling, R., Bracewell, D., and Wall, I. (2018). Manufacturing exosomes: a promising therapeutic platform. Trends Mol Med 24, 242-256.

Contreras-Naranjo, J.C., Wu, H.J., and Ugaz, V.M. (2017). Microfluidics for exosome isolation and analysis: enabling liquid biopsy for personalized medicine. Lab Chip 17, 3558-3577.

Crawford, N. (1971). The presence of contractile proteins in platelet microparticles isolated from human and animal platelet-free plasma. $\mathrm{Br}$ J Haematol 21, 53-69.

Damasceno, P.K.F., de Santana, T.A., Santos, G.C., Orge, I.D., Silva, D.N., Albuquerque, J.F., Golinelli, G., Grisendi, G., Pinelli, M., Ribeiro Dos Santos, R., et al. (2020). Genetic engineering as a strategy to improve the therapeutic efficacy of mesenchymal stem/stromal cells in regenerative medicine. Front Cell Dev Biol 8, 737.

Deregibus, M.C., Figliolini, F., D'Antico, S., Manzini, P.M., Pasquino, C., De Lena, M., Tetta, C., Brizzi, M.F., and Camussi, G. (2016). Chargebased precipitation of extracellular vesicles. Int J Mol Med 38, 1359 1366.

Dominici, M., Le Blanc, K., Mueller, I., Slaper-Cortenbach, I., Marini, F. C., Krause, D.S., Deans, R.J., Keating, A., Prockop, D.J., and Horwitz, E.M. (2006). Minimal criteria for defining multipotent mesenchymal stromal cells. The International Society for Cellular Therapy position statement. Cytotherapy 8, 315-317.

Dreux, M., Garaigorta, U., Boyd, B., Décembre, E., Chung, J., WhittenBauer, C., Wieland, S., and Chisari, F.V. (2012). Short-range exosomal transfer of viral RNA from infected cells to plasmacytoid dendritic cells triggers innate immunity. Cell Host Microbe 12, 558-570.

Du, W., Zhang, K., Zhang, S., Wang, R., Nie, Y., Tao, H., Han, Z., Liang, L., Wang, D., Liu, J., et al. (2017). Enhanced proangiogenic potential of mesenchymal stem cell-derived exosomes stimulated by a nitric oxide releasing polymer. Biomaterials 133, 70-81.

El-Nesr, O.H., Yahiya, S.A., and El-Gazayerly, O.N. (2010). Effect of formulation design and freeze-drying on properties of fluconazole multilamellar liposomes. Saudi Pharm J 18, 217-224.

Faruqu, F.N., Zhou, S., Sami, N., Gheidari, F., Lu, H., and Al-Jamal, K.T. (2020). Three-dimensional culture of dental pulp pluripotent-like stem cells (DPPSCs) enhances Nanog expression and provides a serum-free condition for exosome isolation. FASEB BioAdv 2, 419-433.

Ferguson, S.W., and Nguyen, J. (2016). Exosomes as therapeutics: The implications of molecular composition and exosomal heterogeneity. J Control Release 228, 179-190.

Fernández-Francos, S., Eiro, N., Costa, L.A., Escudero-Cernuda, S., Fernández-Sánchez, M.L., and Vizoso, F.J. (2021). Mesenchymal stem cells as a cornerstone in a galaxy of intercellular signals: basis for a new era of medicine. Int J Mol Sci 22, 3576.

Foroni, C., Zarovni, N., Bianciardi, L., Bernardi, S., Triggiani, L., Zocco, D., Venturella, M., Chiesi, A., Valcamonico, F., and Berruti, A. (2020). When less is more: specific capture and analysis of tumor exosomes in plasma increases the sensitivity of liquid biopsy for comprehensive detection of multiple androgen receptor phenotypes in advanced prostate cancer patients. Biomedicines 8,131 .

Gámez-Valero, A., Monguió-Tortajada, M., Carreras-Planella, L., Franquesa, M., Beyer, K., and Borràs, F.E. (2016). Size-exclusion chromatography-based isolation minimally alters extracellular vesicles' characteristics compared to precipitating agents. Sci Rep 6, 33641.
García-Manrique, P., Gutiérrez, G., and Blanco-López, M.C. (2018). Fully artificial exosomes: towards new theranostic biomaterials. Trends Biotechnol 36, 10-14.

Ge, Q., Zhou, Y., Lu, J., Bai, Y., Xie, X., and Lu, Z. (2014). miRNA in plasma exosome is stable under different storage conditions. Molecules 19, 1568-1575.

Geßner, A., Koch, B., Klann, K., Fuhrmann, D.C., Farmand, S., Schubert, R., Münch, C., Geiger, H., and Baer, P.C. (2021). Characterization of extracellular vesicles from preconditioned human adipose-derived stromal/stem cells. Int J Mol Sci 22, 2873.

Goh, W.J., Zou, S., Ong, W.Y., Torta, F., Alexandra, A.F., Schiffelers, R.M., Storm, G., Wang, J.W., Czarny, B., and Pastorin, G. (2017). Bioinspired cell-derived nanovesicles versus exosomes as drug delivery systems: a cost-effective alternative. Sci Rep 7, 14322.

Greening, D.W., Xu, R., Ji, H., Tauro, B.J., and Simpson, R.J. (2015). A protocol for exosome isolation and characterization: evaluation of ultracentrifugation, density-gradient separation, and immunoaffinity capture methods. Methods Mol Biol 1295, 179-209.

Guimarães, D., Cavaco-Paulo, A., and Nogueira, E. (2021). Design of liposomes as drug delivery system for therapeutic applications. Int $\mathrm{J}$ Pharm 601, 120571

Guo, S., Debbi, L., Zohar, B., Samuel, R., Arzi, R.S., Fried, A.I., Carmon, T., Shevach, D., Redenski, I., Schlachet, I., et al. (2021). Stimulating extracellular vesicles production from engineered tissues by mechanical forces. Nano Lett 21, 2497-2504.

Han, Z., Peng, C., Yi, J., Zhang, D., Xiang, X., Peng, X., Su, B., Liu, B., Shen, Y., and Qiao, L. (2021). Highly efficient exosome purification from human plasma by tangential flow filtration based microfluidic chip. Sens Actuat B-Chem 333, 129563.

Hao, Z.C., Lu, J., Wang, S.Z., Wu, H., Zhang, Y.T., and Xu, S.G. (2017). Stem cell-derived exosomes: A promising strategy for fracture healing. Cell Prolif 50, e12359.

Haraszti, R.A., Didiot, M.C., Sapp, E., Leszyk, J., Shaffer, S.A., Rockwell, H.E., Gao, F., Narain, N.R., DiFiglia, M., Kiebish, M.A., et al. (2016). High-resolution proteomic and lipidomic analysis of exosomes and microvesicles from different cell sources. J Extracell Vesicles 5, 32570 .

Haraszti, R.A., Miller, R., Dubuke, M.L., Rockwell, H.E., Coles, A.H., Sapp, E., Didiot, M.C., Echeverria, D., Stoppato, M., Sere, Y.Y., et al. (2019). Serum deprivation of mesenchymal stem cells improves exosome activity and alters lipid and protein composition. iScience 16, 230-241.

Haraszti, R.A., Miller, R., Stoppato, M., Sere, Y.Y., Coles, A., Didiot, M.C., Wollacott, R., Sapp, E., Dubuke, M.L., Li, X., et al. (2018). Exosomes produced from 3D cultures of MSCs by tangential flow filtration show higher yield and improved activity. Mol Ther 26, 2838-2847.

Harrell, C.R., Jovicic, N., Djonov, V., Arsenijevic, N., and Volarevic, V. (2019). Mesenchymal stem cell-derived exosomes and other extracellular vesicles as new remedies in the therapy of inflammatory diseases. Cells 8, 1605 .

Heinemann, M.L., Ilmer, M., Silva, L.P., Hawke, D.H., Recio, A., Vorontsova, M.A., Alt, E., and Vykoukal, J. (2014). Benchtop isolation and characterization of functional exosomes by sequential filtration. J Chromatogr A 1371, 125-135.

Ishiy, C.S.R.A., Ormanji, M.S., Maquigussa, E., Ribeiro, R.S., da Silva Novaes, A., and Boim, M.A. (2020). Comparison of the effects of mesenchymal stem cells with their extracellular vesicles on the treatment of kidney damage induced by chronic renal artery stenosis. Stem Cells Int 2020, 1-13.

Jamshidi, E., Babajani, A., Soltani, P., and Niknejad, H. (2021). Proposed mechanisms of targeting COVID-19 by delivering mesenchymal stem cells and their exosomes to damaged organs. Stem Cell Rev Rep 17, 176-192.

Jarmalavičiūtè, A., Tunaitis, V., Pivoraitè, U., Venalis, A., and Pivoriūnas, A. (2015). Exosomes from dental pulp stem cells rescue human dopaminergic neurons from 6-hydroxy-dopamine-induced apoptosis. Cytotherapy 17, 932-939. 
Jeyaram, A., and Jay, S.M. (2017). Preservation and storage stability of extracellular vesicles for therapeutic applications. AAPS J 20, 1.

Ji, L., Bao, L., Gu, Z., Zhou, Q., Liang, Y., Zheng, Y., Xu, Y., Zhang, X., and Feng, X. (2019). Comparison of immunomodulatory properties of exosomes derived from bone marrow mesenchymal stem cells and dental pulp stem cells. Immunol Res 67, 432-442.

Ji, Y., Han, W., Fu, X., Li, J., Wu, Q., and Wang, Y. (2021). Improved small extracellular vesicle secretion of rat adipose-derived stem cells by microgrooved substrates through upregulation of the ESCRT-IIIassociated protein alix. Adv Healthcare Mater 10, 2100492.

Jin, Y., Chen, K., Wang, Z., Wang, Y., Liu, J., Lin, L., Shao, Y., Gao, L., Yin, H., Cui, C., et al. (2016). DNA in serum extracellular vesicles is stable under different storage conditions. BMC Cancer 16, 753.

Jo, W., Jeong, D., Kim, J., Cho, S., Jang, S.C., Han, C., Kang, J.Y., Gho, Y. S., and Park, J. (2014). Microfluidic fabrication of cell-derived nanovesicles as endogenous RNA carriers. Lab Chip 14, 1261-1269.

Jo, W., Kim, J., Yoon, J., Jeong, D., Cho, S., Jeong, H., Yoon, Y.J., Kim, S. C., Gho, Y.S., and Park, J. (2014). Large-scale generation of cellderived nanovesicles. Nanoscale 6, 12056-12064.

Kalluri, R., and LeBleu, V.S. (2020). The biology, function, and biomedical applications of exosomes. Science 367, eaau6977.

Kamerkar, S., LeBleu, V.S., Sugimoto, H., Yang, S., Ruivo, C.F., Melo, S. A., Lee, J.J., and Kalluri, R. (2017). Exosomes facilitate therapeutic targeting of oncogenic KRAS in pancreatic cancer. Nature 546, 498503.

Kamiya, K., Osaki, T., and Takeuchi, S. (2021). Formation of nano-sized lipid vesicles with asymmetric lipid components using a pulsed-jet flow method. Sens Actuat B-Chem 327, 128917.

Kang, D., Oh, S., Ahn, S.M., Lee, B.H., and Moon, M.H. (2008). Proteomic analysis of exosomes from human neural stem cells by flow field-flow fractionation and nanoflow liquid chromatography-tandem mass spectrometry. J Proteome Res 7, 3475-3480.

Katzmann, D.J., Babst, M., and Emr, S.D. (2001). Ubiquitin-dependent sorting into the multivesicular body pathway requires the function of a conserved endosomal protein sorting complex, ESCRT-I. Cell 106, $145-155$.

Kim, M., Yun, H.W., Park, D.Y., Choi, B.H., and Min, B.H. (2018). Threedimensional spheroid culture increases exosome secretion from mesenchymal stem cells. Tissue Eng Regen Med 15, 427-436.

Kita, S., and Shimomura, I. (2020). Stimulation of exosome biogenesis by adiponectin, a circulating factor secreted from adipocytes. J Biochem $169,173-179$.

Koh, B., Sulaiman, N., Fauzi, M.B., Law, J.X., Ng, M.H., Idrus, R.B.H., and Yazid, M.D. (2020). Three dimensional microcarrier system in mesenchymal stem cell culture: a systematic review. Cell Biosci 10, 75 .

Kornmuller, A., Brown, C.F.C., Yu, C., and Flynn, L.E. (2017). Fabrication of Extracellular Matrix-derived Foams and Microcarriers as Tissuespecific Cell Culture and Delivery Platforms. J Vis Exp, , doi: 10.3791/ 55436.

Kosaka, N., Yoshioka, Y., Hagiwara, K., Tominaga, N., and Ochiya, T. (2013). Functional analysis of exosomal microRNA in cell-cell communication research. Methods Mol Biol 1024, 1-10.

Kowal, J., Tkach, M., and Théry, C. (2014). Biogenesis and secretion of exosomes. Curr Opin Cell Biol 29, 116-125.

Kuriyan, A.E., Albini, T.A., Townsend, J.H., Rodriguez, M., Pandya, H.K., Leonard Ii, R.E., Parrott, M.B., Rosenfeld, P.J., Flynn Jr., H.W., and Goldberg, J.L. (2017). Vision loss after intravitreal injection of autologous "stem cells" for AMD. N Engl J Med 376, 1047-1053.

Kyung Kim, D., Lee, S., Kim, M., Jeong, Y., and Lee, S. (2021). Exosomecoated silk fibroin 3D-scaffold for inducing osteogenic differentiation of bone marrow derived mesenchymal stem cells. Chem Eng J 406, 127080 .

Lai, R.C., Arslan, F., Lee, M.M., Sze, N.S.K., Choo, A., Chen, T.S., SaltoTellez, M., Timmers, L., Lee, C.N., El Oakley, R.M., et al. (2010). Exosome secreted by MSC reduces myocardial ischemia/reperfusion injury. Stem Cell Res 4, 214-222.

Lane, R.E., Korbie, D., Trau, M., and Hill, M.M. (2017). Purification protocols for extracellular vesicles. Methods Mol Biol 1660, 111-130.

Lee, B.C., Kang, I., and Yu, K.R. (2021). Therapeutic features and updated clinical trials of mesenchymal stem cell (MSC)-derived exosomes. J Clin Med 10, 711 .

Lee, H., Cha, H., and Park, J.H. (2020). Derivation of cell-engineered nanovesicles from human induced pluripotent stem cells and their protective effect on the senescence of dermal fibroblasts. Int J Mol Sci $21,343$.

Lee, K., Shao, H., Weissleder, R., and Lee, H. (2015). Acoustic purification of extracellular microvesicles. ACS Nano 9, 2321-2327.

Li, J., Lee, Y., Johansson, H.J., Mäger, I., Vader, P., Nordin, J.Z., Wiklander, O.P.B., Lehtiö, J., Wood, M.J.A., and Andaloussi, S.E. (2015). Serum-free culture alters the quantity and protein composition of neuroblastoma-derived extracellular vesicles. J Extracell Vesicles 4, 26883.

Li, K., Chang, S., Wang, Z., Zhao, X., and Chen, D. (2015). A novel microemulsion and micelle assembling method to prepare DEC205 monoclonal antibody coupled cationic nanoliposomes for simulating exosomes to target dendritic cells. Int J Pharm 491, 105-112.

Li, P., Kaslan, M., Lee, S.H., Yao, J., and Gao, Z. (2017). Progress in exosome isolation techniques. Theranostics 7, 789-804.

Li, S.P., Lin, Z.X., Jiang, X.Y., and Yu, X.Y. (2018). Exosomal cargoloading and synthetic exosome-mimics as potential therapeutic tools. Acta Pharmacol Sin 39, 542-551.

Lin, Y., Wu, J., Gu, W., Huang, Y., Tong, Z., Huang, L., and Tan, J. (2018). Exosome-liposome hybrid nanoparticles deliver CRISPR/Cas9 system in MSCs. Adv Sci 5, 1700611.

Ling, Y., Xu, W., Yang, L., Liang, C., and Xu, B. (2020). Improved the biocompatibility of cancellous bone with compound physicochemical decellularization process. Regen Biomater 7, 443-451.

Liu, C., Guo, J., Tian, F., Yang, N., Yan, F., Ding, Y., Wei, J.Y., Hu, G., Nie, G., and Sun, J. (2017). Field-free isolation of exosomes from extracellular vesicles by microfluidic viscoelastic flows. ACS Nano 11, 6968-6976.

Liu, C., and Su, C. (2019). Design strategies and application progress of therapeutic exosomes. Theranostics 9, 1015-1028.

Liu, L., Liu, Y., Feng, C., Chang, J., Fu, R., Wu, T., Yu, F., Wang, X., Xia, L., Wu, C., et al. (2019). Lithium-containing biomaterials stimulate bone marrow stromal cell-derived exosomal miR-130a secretion to promote angiogenesis. Biomaterials 192, 523-536.

Liu, W., Rong, Y., Wang, J., Zhou, Z., Ge, X., Ji, C., Jiang, D., Gong, F., Li, L., Chen, J., et al. (2020). Exosome-shuttled miR-216a-5p from hypoxic preconditioned mesenchymal stem cells repair traumatic spinal cord injury by shifting microglial M1/M2 polarization. J Neuroinflam 17, 47.

Lobb, R.J., Becker, M., Wen Wen, S., Wong, C.S.F., Wiegmans, A.P., Leimgruber, A., and Möller, A. (2015). Optimized exosome isolation protocol for cell culture supernatant and human plasma. J Extracell Vesicles 4, 27031.

Lopez-Verrilli, M.A., Caviedes, A., Cabrera, A., Sandoval, S., Wyneken, U., and Khoury, M. (2016). Mesenchymal stem cell-derived exosomes from different sources selectively promote neuritic outgrowth. Neuroscience 320, 129-139.

Luo, L., Tang, J., Nishi, K., Yan, C., Dinh, P.U., Cores, J., Kudo, T., Zhang, J., Li, T.S., and Cheng, K. (2017). Fabrication of synthetic mesenchymal stem cells for the treatment of acute myocardial infarction in mice. Circ Res 120, 1768-1775.

Maroto, R., Zhao, Y., Jamaluddin, M., Popov, V.L., Wang, H., Kalubowilage, M., Zhang, Y., Luisi, J., Sun, H., Culbertson, C.T., et al. (2017). Effects of storage temperature on airway exosome integrity for diagnostic and functional analyses. J Extracell Vesicles 6, 1359478.

Martinelli, C., Gabriele, F., Dini, E., Carriero, F., Bresciani, G., Slivinschi, B., Dei Giudici, M., Zanoletti, L., Manai, F., Paolillo, M., et al. (2020). Development of artificial plasma membranes derived nanovesicles suitable for drugs encapsulation. Cells 9, 1626.

Massa, M., Croce, S., Campanelli, R., Abbà, C., Lenta, E., Valsecchi, C., and Avanzini, M.A. (2020). Clinical applications of mesenchymal stem/ stromal cell derived extracellular vesicles: therapeutic potential of an 
acellular product. Diagnostics 10, 999.

McBride, J.D., Rodriguez-Menocal, L., Guzman, W., Candanedo, A., Garcia-Contreras, M., and Badiavas, E.V. (2017). Bone marrow mesenchymal stem cell-derived $\mathrm{CD}^{+} 3^{+}$exosomes transport Wnt3a exteriorly and enhance dermal fibroblast proliferation, migration, and angiogenesis in vitro. Stem Cells Dev 26, 1384-1398.

Mehryab, F., Rabbani, S., Shahhosseini, S., Shekari, F., Fatahi, Y., Baharvand, H., and Haeri, A. (2020). Exosomes as a next-generation drug delivery system: An update on drug loading approaches, characterization, and clinical application challenges. Acta Biomater $113,42-62$

Mendt, M., Rezvani, K., and Shpall, E. (2019). Mesenchymal stem cellderived exosomes for clinical use. Bone Marrow Transplant 54, 789 792

Mianehsaz, E., Mirzaei, H.R., Mahjoubin-Tehran, M., Rezaee, A., Sahebnasagh, R., Pourhanifeh, M.H., Mirzaei, H., and Hamblin, M.R. (2019). Mesenchymal stem cell-derived exosomes: a new therapeutic approach to osteoarthritis? Stem Cell Res Ther 10, 340.

Moleirinho, M.G., Silva, R.J.S., Carrondo, M.J.T., Alves, P.M., and Peixoto, C. (2019). Exosome-based therapeutics: Purification using semi-continuous multi-column chromatography. Sep Purif Technol 224, $515-523$.

Montecalvo, A., Larregina, A.T., and Morelli, A.E. (2013). Methods of analysis of dendritic cell-derived exosome-shuttle microRNA and its horizontal propagation between dendritic cells. Methods Mol Biol 1024, $19-40$.

Musante, L., Tataruch, D., Gu, D., Benito-Martin, A., Calzaferri, G., Aherne, S., and Holthofer, H. (2014). A simplified method to recover urinary vesicles for clinical applications and sample banking. Sci Rep 4, 7532.

Nakamura, Y., Miyaki, S., Ishitobi, H., Matsuyama, S., Nakasa, T., Kamei, N., Akimoto, T., Higashi, Y., and Ochi, M. (2015). Mesenchymal-stemcell-derived exosomes accelerate skeletal muscle regeneration. FEBS Lett $589,1257-1265$.

Nordin, J.Z., Lee, Y., Vader, P., Mäger, I., Johansson, H.J., Heusermann, W., Wiklander, O.P.B., Hällbrink, M., Seow, Y., Bultema, J.J., et al. (2015). Ultrafiltration with size-exclusion liquid chromatography for high yield isolation of extracellular vesicles preserving intact biophysical and functional properties. Nanomed-Nanotechnol Biol Med 11, 879-883.

Novoseletskaya, E.S., Grigorieva, O.A., Efimenko, A.Y., and Kalinina, N.I. (2019). Extracellular matrix in the regulation of stem cell differentiation. Biochem Moscow 84, 232-240.

Obata, Y., Kita, S., Koyama, Y., Fukuda, S., Takeda, H., Takahashi, M., Fujishima, Y., Nagao, H., Masuda, S., Tanaka, Y., et al. (2018). Adiponectin/T-cadherin system enhances exosome biogenesis and decreases cellular ceramides by exosomal release. JCI Insight 3 , e99680.

Oosthuyzen, W., Sime, N.E.L., Ivy, J.R., Turtle, E.J., Street, J.M., Pound, J., Bath, L.E., Webb, D.J., Gregory, C.D., Bailey, M.A., et al. (2013). Quantification of human urinary exosomes by nanoparticle tracking analysis. J Physiol 591, 5833-5842.

Ostrowski, M., Carmo, N.B., Krumeich, S., Fanget, I., Raposo, G., Savina, A., Moita, C.F., Schauer, K., Hume, A.N., Freitas, R.P., et al. (2010). Rab27a and Rab27b control different steps of the exosome secretion pathway. Nat Cell Biol 12, 19-30.

Park, D.J., Yun, W.S., Kim, W.C., Park, J.E., Lee, S.H., Ha, S., Choi, J.S., Key, J., and Seo, Y.J. (2020). Improvement of stem cell-derived exosome release efficiency by surface-modified nanoparticles. J Nanobiotechnol 18, 178

Patel, D.B., Luthers, C.R., Lerman, M.J., Fisher, J.P., and Jay, S.M. (2019). Enhanced extracellular vesicle production and ethanol-mediated vascularization bioactivity via a 3D-printed scaffold-perfusion bioreactor system. Acta Biomater 95, 236-244.

Peng, K.Y., Liu, Y.H., Li, Y.W., Yen, B.L., and Yen, M.L. (2017) Extracellular matrix protein laminin enhances mesenchymal stem cell (MSC) paracrine function through $\alpha \mathrm{v} \beta 3 / \mathrm{CD} 61$ integrin to reduce cardiomyocyte apoptosis. J Cell Mol Med 21, 1572-1583.

Phinney, D.G., and Pittenger, M.F. (2017). Concise review: MSC-derived exosomes for cell-free therapy. Stem Cells 35, 851-858.

Piffoux, M., Silva, A.K.A., Wilhelm, C., Gazeau, F., and Tareste, D. (2018). Modification of extracellular vesicles by fusion with liposomes for the design of personalized biogenic drug delivery systems. ACS Nano 12, 6830-6842.

Pusic, K.M., Pusic, A.D., and Kraig, R.P. (2016). Environmental enrichment stimulates immune cell secretion of exosomes that promote CNS myelination and may regulate inflammation. Cell Mol Neurobiol 36, 313-325.

Qin, B., Zhang, Q., Hu, X.M., Mi, T.Y., Yu, H.Y., Liu, S.S., Zhang, B., Tang, M., Huang, J.F., and Xiong, K. (2020). How does temperature play a role in the storage of extracellular vesicles? J Cell Physiol 235, $7663-7680$.

Qu, Y., Zhang, Q., Cai, X., Li, F., Ma, Z., Xu, M., and Lu, L. (2017). Exosomes derived from miR-181-5p-modified adipose-derived mesenchymal stem cells prevent liver fibrosis via autophagy activation. J Cell Mol Med 21, 2491-2502.

Ratajczak, J., Miekus, K., Kucia, M., Zhang, J., Reca, R., Dvorak, P., and Ratajczak, M.Z. (2006). Embryonic stem cell-derived microvesicles reprogram hematopoietic progenitors: evidence for horizontal transfer of mRNA and protein delivery. Leukemia 20, 847-856.

Rekker, K., Saare, M., Roost, A.M., Kubo, A.L., Zarovni, N., Chiesi, A., Salumets, A., and Peters, M. (2014). Comparison of serum exosome isolation methods for microRNA profiling. Clin Biochem 47, 135-138.

Richter, M., Fuhrmann, K., and Fuhrmann, G. (2019). Evaluation of the storage stability of extracellular vesicles. J Vis Exp, , doi: 10.3791/ 59584.

Ruan, X.F., Ju, C.W., Shen, Y., Liu, Y.T., Kim, I.M., Yu, H., Weintraub, N., Wang, X.L., and Tang, Y. (2018). Suxiao Jiuxin pill promotes exosome secretion from mouse cardiac mesenchymal stem cells in vitro. Acta Pharmacol Sin 39, 569-578.

Ryu, K.J., Lee, J.Y., Park, C., Cho, D., and Kim, S.J. (2020). Isolation of small extracellular vesicles from human serum using a combination of ultracentrifugation with polymer-based precipitation. Ann Lab Med 40, 253-258.

Sakai-Kato, K., Yoshida, K., Takechi-Haraya, Y., and Izutsu, K.I. (2020). Physicochemical characterization of liposomes that mimic the lipid composition of exosomes for effective intracellular trafficking. Langmuir 36, 12735-12744.

Sarker, S., Scholz-Romero, K., Perez, A., Illanes, S.E., Mitchell, M.D., Rice, G.E., and Salomon, C. (2014). Placenta-derived exosomes continuously increase in maternal circulation over the first trimester of pregnancy. J Transl Med 12, 204.

Schiffelers, R., Kooijmans, S., Vader, S., van Dommelen, S., and Van Solinge, S. (2012). Exosome mimetics: a novel class of drug delivery systems. Int J Nanomed 7, 1525-1541.

Sharma, A. (2018). Role of stem cell derived exosomes in tumor biology. Int J Cancer 142, 1086-1092.

Shi, J., Jiang, X., Gao, S., Zhu, Y., Liu, J., Gu, T., and Shi, E. (2021). Genemodified exosomes protect the brain against prolonged deep hypothermic circulatory arrest. Ann Thoracic Surg 111, 576-585.

Silva, A.K.A., Luciani, N., Gazeau, F., Aubertin, K., Bonneau, S., Chauvierre, C., Letourneur, D., and Wilhelm, C. (2015). Combining magnetic nanoparticles with cell derived microvesicles for drug loading and targeting. Nanomed-Nanotechnol Biol Med 11, 645-655.

Sterzenbach, U., Putz, U., Low, L.H., Silke, J., Tan, S.S., and Howitt, J. (2017). Engineered exosomes as vehicles for biologically active proteins. Mol Ther 25, 1269-1278.

Strauss, K., Goebel, C., Runz, H., Möbius, W., Weiss, S., Feussner, I., Simons, M., and Schneider, A. (2010). Exosome secretion ameliorates lysosomal storage of cholesterol in Niemann-Pick type C disease. J Biol Chem 285, 26279-26288.

Sundaram, P.M., Casadei, L., Lopez, G., Braggio, D., Balakirsky, G., Pollock, R., and Prakash, S. (2020). Multi-layer micro-nanofluidic device for isolation and capture of extracellular vesicles derived from 
liposarcoma cell conditioned media. J Microelectromech Syst 29, 776782.

Surman, M., Drożdż, A., Stępień, E., and Przybyło, M. (2019). Extracellular vesicles as drug delivery systems-methods of production and potential therapeutic applications. Curr Pharm Des 25, $132-154$.

Tang, J., Shen, D., Caranasos, T.G., Wang, Z., Vandergriff, A.C., Allen, T. A., Hensley, M.T., Dinh, P.U., Cores, J., Li, T.S., et al. (2017). Therapeutic microparticles functionalized with biomimetic cardiac stem cell membranes and secretome. Nat Commun 8, 13724.

Tang, Y.T., Huang, Y.Y., Zheng, L., Qin, S.H., Xu, X.P., An, T.X., Xu, Y., Wu, Y.S., Hu, X.M., Ping, B.H., et al. (2017). Comparison of isolation methods of exosomes and exosomal RNA from cell culture medium and serum. Int J Mol Med 40, 834-844.

Tauro, B.J., Greening, D.W., Mathias, R.A., Ji, H., Mathivanan, S., Scott, A.M., and Simpson, R.J. (2012). Comparison of ultracentrifugation, density gradient separation, and immunoaffinity capture methods for isolating human colon cancer cell line LIM1863-derived exosomes. Methods 56, 293-304.

Tavassoli, H., Alhosseini, S.N., Tay, A., Chan, P.P.Y., Weng Oh, S.K., and Warkiani, M.E. (2018). Large-scale production of stem cells utilizing microcarriers: A biomaterials engineering perspective from academic research to commercialized products. Biomaterials 181, 333-346.

Tegegn, T.Z., De Paoli, S.H., Orecna, M., Elhelu, O.K., Woodle, S.A., Tarandovskiy, I.D., Ovanesov, M.V., and Simak, J. (2016). Characterization of procoagulant extracellular vesicles and platelet membrane disintegration in DMSO-cryopreserved platelets. J Extracell Vesicles 5, 30422.

Ti, D., Hao, H., Tong, C., Liu, J., Dong, L., Zheng, J., Zhao, Y., Liu, H., Fu, X., and Han, W. (2015). LPS-preconditioned mesenchymal stromal cells modify macrophage polarization for resolution of chronic inflammation via exosome-shuttled let-7b. J Transl Med 13, 308.

Toledano Furman, N.E., Lupu-Haber, Y., Bronshtein, T., Kaneti, L., Letko, N., Weinstein, E., Baruch, L., and Machluf, M. (2013). Reconstructed stem cell nanoghosts: a natural tumor targeting platform. Nano Lett 13, 3248-3255.

Trajkovic, K., Hsu, C., Chiantia, S., Rajendran, L., Wenzel, D., Wieland, F., Schwille, P., Brügger, B., and Simons, M. (2008). Ceramide triggers budding of exosome vesicles into multivesicular endosomes. Science 319, 1244-1247.

Tsintou, M., Dalamagkas, K., Moore, T.L., Rathi, Y., Kubicki, M., Rosene, D.L., and Makris, N. (2021). The use of hydrogel-delivered extracellular vesicles in recovery of motor function in stroke: a testable experimental hypothesis for clinical translation including behavioral and neuroimaging assessment approaches. Neural Regen Res 16, 605 .

Turner, A.E.B., and Flynn, L.E. (2012). Design and characterization of tissue-specific extracellular matrix-derived microcarriers. Tissue Eng Part C-Methods 18, 186-197.

Ueda, K., Ishikawa, N., Tatsuguchi, A., Saichi, N., Fujii, R., and Nakagawa, H. (2014). Antibody-coupled monolithic silica microtips for highthroughput molecular profiling of circulating exosomes. Sci Rep 4, 6232.

van der Meel, R., Fens, M.H.A.M., Vader, P., van Solinge, W.W., EniolaAdefeso, O., and Schiffelers, R.M. (2014). Extracellular vesicles as drug delivery systems: lessons from the liposome field. J Control Release 195, 72-85.

Van Deun, J., Roux, Q., Deville, S., Van Acker, T., Rappu, P., Miinalainen, I., Heino, J., Vanhaecke, F., De Geest, B.G., De Wever, O., et al. (2020). Feasibility of mechanical extrusion to coat nanoparticles with extracellular vesicle membranes. Cells 9, 1797.

Vázquez-Ríos, A.J., Molina-Crespo, Á., Bouzo, B.L., López-López, R., Moreno-Bueno, G., and de la Fuente, M. (2019). Exosome-mimetic nanoplatforms for targeted cancer drug delivery. J Nanobiotechnol 17, 85.

Wang, C., Liang, C., Wang, R., Yao, X., Guo, P., Yuan, W., Liu, Y., Song, Y., Li, Z., and Xie, X. (2019a). The fabrication of a highly efficient self- healing hydrogel from natural biopolymers loaded with exosomes for the synergistic promotion of severe wound healing. Biomater Sci 8, 313-324.

Wang, C., Wang, M., Xu, T., Zhang, X., Lin, C., Gao, W., Xu, H., Lei, B., and Mao, C. (2019b). Engineering bioactive self-healing antibacterial exosomes hydrogel for promoting chronic diabetic wound healing and complete skin regeneration. Theranostics 9, 65-76.

Wang, J., Bonacquisti, E.E., Brown, A.D., and Nguyen, J. (2020). Boosting the biogenesis and secretion of mesenchymal stem cell-derived exosomes. Cells 9, 660 .

Welch, J.L., Madison, M.N., Margolick, J.B., Galvin, S., Gupta, P., Martínez-Maza, O., Dash, C., and Okeoma, C.M. (2017). Effect of prolonged freezing of semen on exosome recovery and biologic activity. Sci Rep 7, 45034.

Witwer, K.W., Buzás, E.I., Bemis, L.T., Bora, A., Lässer, C., Lötvall, J., Nolte-'t Hoen, E.N., Piper, M.G., Sivaraman, S., Skog, J., et al. (2013). Standardization of sample collection, isolation and analysis methods in extracellular vesicle research. J Extracell Vesicles 2, 20360.

Wu, J.Y., Li, Y.J., Hu, X.B., Huang, S., and Xiang, D.X. (2021). Preservation of small extracellular vesicles for functional analysis and therapeutic applications: a comparative evaluation of storage conditions. Drug Deliver 28, 162-170.

Wu, Z., He, D., and Li, H. (2021). Bioglass enhances the production of exosomes and improves their capability of promoting vascularization. Bioactive Mater 6, 823-835.

Xu, C., Zhao, J., Li, Q., Hou, L., Wang, Y., Li, S., Jiang, F., Zhu, Z., and Tian, L. (2020). Exosomes derived from three-dimensional cultured human umbilical cord mesenchymal stem cells ameliorate pulmonary fibrosis in a mouse silicosis model. Stem Cell Res Ther 11, 503.

Yan, L., Liu, G., and Wu, X. (2021). Exosomes derived from umbilical cord mesenchymal stem cells in mechanical environment show improved osteochondral activity via upregulation of LncRNA H19. J Orthop Transl 26, 111-120.

Yan, X., Zhang, K., Yang, Y., Deng, D., Lyu, C., Xu, H., Liu, W., and Du, Y. (2020). Dispersible and dissolvable porous microcarrier tablets enable efficient large-scale human mesenchymal stem cell expansion. Tissue Eng Part C-Methods 26, 263-275.

Yáñez-Mó, M., Siljander, P.R.M., Andreu, Z., Bedina Zavec, A., Borràs, F. E., Buzas, E.I., Buzas, K., Casal, E., Cappello, F., Carvalho, J., et al. (2015). Biological properties of extracellular vesicles and their physiological functions. J Extracell Vesicles 4, 27066.

Yang, D., Zhang, W., Zhang, H., Zhang, F., Chen, L., Ma, L., Larcher, L. M., Chen, S., Liu, N., Zhao, Q., et al. (2020). Progress, opportunity, and perspective on exosome isolation-efforts for efficient exosome-based theranostics. Theranostics 10, 3684-3707.

Yang, Z., Shi, J., Xie, J., Wang, Y., Sun, J., Liu, T., Zhao, Y., Zhao, X., Wang, X., Ma, Y., et al. (2020). Large-scale generation of functional mRNA-encapsulating exosomes via cellular nanoporation. Nat Biomed Eng 4, 69-83.

Yao, C., Wu, W., Tang, H., Jia, X., Tang, J., Ruan, X., Li, F., Leong, D.T., Luo, D., and Yang, D. (2020). Self-assembly of stem cell membranecamouflaged nanocomplex for microRNA-mediated repair of myocardial infarction injury. Biomaterials 257, 120256.

Yin, J.Q., Zhu, J., and Ankrum, J.A. (2019). Manufacturing of primed mesenchymal stromal cells for therapy. Nat Biomed Eng 3, 90-104.

Yoon, J., Jo, W., Jeong, D., Kim, J., Jeong, H., and Park, J. (2015). Generation of nanovesicles with sliced cellular membrane fragments for exogenous material delivery. Biomaterials 59, 12-20.

Yuan, Y., Du, W., Liu, J., Ma, W., Zhang, L., Du, Z., and Cai, B. (2018). Stem cell-derived exosome in cardiovascular diseases: macro roles of micro particles. Front Pharmacol 9, 547.

Zakrzewski, W., Dobrzyński, M., Szymonowicz, M., and Rybak, Z. (2019). Stem cells: past, present, and future. Stem Cell Res Ther 10, 68.

Zarovni, N., Corrado, A., Guazzi, P., Zocco, D., Lari, E., Radano, G., Muhhina, J., Fondelli, C., Gavrilova, J., and Chiesi, A. (2015). Integrated isolation and quantitative analysis of exosome shuttled proteins and nucleic acids using immunocapture approaches. Methods 
$87,46-58$.

Zeringer, E., Barta, T., Li, M., and Vlassov, A.V. (2015). Strategies for isolation of exosomes. Cold Spring Harb Protoc 2015(4), pdb. top074476.

Zhai, M., Zhu, Y., Yang, M., and Mao, C. (2020). human mesenchymal stem cell derived exosomes enhance cell-free bone regeneration by altering their miRNAs profiles. Adv Sci 7, 2001334.

Zhang, D., Lee, H., Zhu, Z., Minhas, J.K., and Jin, Y. (2017). Enrichment of selective miRNAs in exosomes and delivery of exosomal miRNAs in vitro and in vivo. Am J Physiol-Lung Cell Mol Physiol 312, L110L121.

Zhang, H., and Lyden, D. (2019). Asymmetric-flow field-flow fractionation technology for exomere and small extracellular vesicle separation and characterization. Nat Protoc 14, 1027-1053.

Zhang, J., Nguyen, L.T.H., Hickey, R., Walters, N., Wang, X., Kwak, K.J., Lee, L.J., Palmer, A.F., and Reátegui, E. (2021). Immunomagnetic sequential ultrafiltration (iSUF) platform for enrichment and purification of extracellular vesicles from biofluids. Sci Rep 11, 8034 .

Zhao, L., Wang, Y., and Zhang, Y. (2020). The potential diagnostic and therapeutic applications of exosomes in drug-induced liver injury. Toxicol Lett 337, 68-77.

Zhou, H., Yuen, P.S.T., Pisitkun, T., Gonzales, P.A., Yasuda, H., Dear, J.W., Gross, P., Knepper, M.A., and Star, R.A. (2006). Collection, storage, preservation, and normalization of human urinary exosomes for biomarker discovery. Kidney Int 69, 1471-1476.

Zhu, L.P., Tian, T., Wang, J.Y., He, J.N., Chen, T., Pan, M., Xu, L., Zhang, H.X., Qiu, X.T., Li, C.C., et al. (2018). Hypoxia-elicited mesenchymal stem cell-derived exosomes facilitates cardiac repair through miR$125 \mathrm{~b}$-mediated prevention of cell death in myocardial infarction. Theranostics 8, 6163-6177.

Zonneveld, M.I., Brisson, A.R., van Herwijnen, M.J.C., Tan, S., van de Lest, C.H.A., Redegeld, F.A., Garssen, J., Wauben, M.H.M., and Nolte-' t Hoen, E.N.M. (2014). Recovery of extracellular vesicles from human breast milk is influenced by sample collection and vesicle isolation procedures. J Extracell Vesicles 3, 24215.

Zou, W., Lai, M., Zhang, Y., Zheng, L., Xing, Z., Li, T., Zou, Z., Song, Q., Zhao, X., Xia, L., et al. (2019). Exosome release is regulated by mTORC1. Adv Sci 6, 1801313. 